\title{
Exploring the emancipatory dimensions of globalisation: the struggle over IFRS8 and country-by-country reporting.
}

CRAWFORD, L.

2019 


\title{
Exploring the emancipatory dimensions of globalisation: the struggle over IFRS8 and country-by-country reporting
}

\begin{abstract}
This paper unravels how Publish What You Pay (PWYP), a transnational social movement organisation campaigning for transparency reporting in the extractive sector to improve the lives of women, men and children in resource-rich countries, successfully mobilised emancipatory accounting change in the context of globalisation. Social movement theory helps explain how PWYP used political opportunity structures available in the International Accounting Standards Board's (IASB) due process, in an attempt to persuade IASB to adopt [a form of] country-bycountry reporting for transnational extractive companies. Locating the research on the political and publicised struggle surrounding IASB's adoption of International Financial Reporting Standard (IFRS) 8 - Operating Segments, the research finds PWYP was unsuccessful in persuading IASB to adopt country-by-country reporting. Despite this setback, and assisted by the unfolding drama of the global financial crisis, PWYP's capacity to frame arguments, form alliances, evolve tactics and shift the target of its agency in response to institutional dynamics, meant they were ultimately successful in innovating, diffusing and instituting [a form of] mandatory country-by-country reporting in Europe and beyond. Such incremental emancipatory accounting change evidences a shift in the balance of power over accounting's processual development away from IASB and neoliberal hegemonic forces. The findings of this research lend substance to Gallhofer and Haslam's (2007) rescuing critique of constructing an international emancipatory accounting, emerging from globalisation's embedded conflicts, consistent with their (2006) post-Marxist thesis of "continuum thinking orientated through struggle" (p.910).
\end{abstract}

Key words: emancipatory; globalisation; social movement theory; country-by-country reporting (CbCR), diffusion. 


\section{Introduction}

The aim of this paper is to explore emancipatory dimensions of international accounting in action in the context of globalisation. Building on the work of Gallhofer and Haslam (2007), who offer a rescuing critique of globalisation's embedded potential for civil society intervention in accounting's development, this paper evidences social movement action to mobilise emancipatory accounting, in [a form of] country-by-country reporting (CbCR). The timeframe explored starts in 2006, the year Publish What You Pay (PWYP) found a window of opportunity in the International Accounting Standards Board's (IASB) due process consultation which preceded adoption of International Financial Reporting Standard (IFRS) 8 - 'Operating Segments'. This is also the year after PWYP hired an accounting expert to advise and develop the accounting-practice mechanism for achieving CbCR for Transnational Companies (TNCs) operating in resource-rich countries (PWYP, 2005a). ${ }^{1}$ The research continues until 2013, when (i) IASB published the outcome of its inaugural post-implementation review, which it exercised over IFRS8 (IFRS Foundations, 2013a), and (ii) the EU Accounting and Transparency Directives, mandating [a form of] CbCR, were adopted by the European Parliament (European Commission, 2013).

Using social movement theory, this research shows how PWYP's capacity to frame arguments, form alliances, evolve tactics and shift the target of their agency in response to institutional dynamics, meant they were ultimately successful in diffusing [a form of] mandatory country-bycountry reporting in Europe and beyond, after their earlier attempts to persuade IASB to adopt $\mathrm{CbCR}$ had failed. In so doing, two emancipatory moments are illuminated. First, an elaboration of IASB's due process to include a post-implementation review, where IASB actively seeks contribution from a wide demographic of interested parties, together with the disentanglement of IASB-FASB's powerful alliance, evidences development of a more democratic process for setting accounting standards for transnational companies. Second, evidence of international accounting's processual development leveraged by civil society agency to innovate, diffuse and institute for the first time, an emancipatory accounting practice to account for [some] social consequences of international business, in addition to the economic consequences for global capital market participants. This paper argues that the IFRS8 affair initiated a shift in the balance of power over accounting's development, facilitated by the drama and opportunity of the global financial crisis (GFC), away from a narrower and quite singular focus on providing information for neoliberal capitalism $^{2}$, to include information for advancing the well-being of citizens.

Globalisation presents a context where disruption, disagreement and culture clashes produce a rich environment for alternative ideologies to be debated and awareness of global issues publicised. Globalisation has been described by Gallhofer and Haslam (2006) as a dynamic phenomenon that has supported the spread of international organisations operating at a level beyond individual state control. Supra-state organisations take the form of: for-profit TNCs; international governmental

\footnotetext{
${ }^{1}$ PWYP's central contestation concerns the resource-curse, therefore they focus on campaigning for transparency reporting in the extractive sector. However, PWYP also advocate CbCR for all transnational companies (PWYP 2005a).

${ }^{2}$ Neoliberal capitalism is characterised by: privatisation, financialisation, fiscal austerity, deregulation, free trade and a reduction in government spending with advocates arguing that effective and efficient neoliberal capital markets will enhance the wealth and wellbeing of individual citizens.
} 
organisation (IGOs), for example United Nations organisations and committees of the European Parliament; and international non-governmental organisations (INGOs), encompassing diverse organisations such as the IASB, and international charities. Within this last category exists transnational social movement organisations, such as PWYP, working to globalise protest and institute change for the good of "a global civil society" (della Porta and Kriesi, 2009, px; Passy, 2009). Social movements, as agents of change, use a repertoire of contestation, collective action, framing and self-conscious mobilisation (della Porta and Kriesi, 2009; Schneiberg and Lounsbury, 2008).

Gallhofer and Haslam (2006) argue that "positive potentiality and opportunity can be found" (p.904) in the interaction between the social development of accounting practice and globalisation's embedded tensions and conflicts. Brown (2017) also argues that conflict-ridden pluralism in Anglo-American capitalism provides promising opportunities for emancipatory accounting interventions. However, in the absence of state-regulation, organisational power in the field of setting international accounting standards for TNCs, has been problematic, with corporate regulation shifting "from local monopoly to global cartel" (Suddaby et al., 2007). Specifically, contemporary international accounting emphasises measuring and communicating the economic consequences of international business to "foster trust, growth and long-term financial stability in the global economy" (IFRS Foundation, 2015a), supporting neoliberal capitalism. ${ }^{3}$ There is convincing evidence, however, that neoliberal capitalism contributes to marginalising and exploiting citizens' civil rights ${ }^{4}$ in favour of generating wealth for capital market participants (Lehman, 2005; PWYP, 2005; Gallhofer and Haslam, 2006, 2007; Roulet, 2014, Palea, 2015 Brown, 2017; Chiapello, 2017). Most recently, researchers at the International Monetary Fund (IMF), an international finance institution supporting neoliberal ideals to enable developing countries to 'develop', have issued a report stating that the concept of neoliberalism has been "oversold", particularly in relation to sustained abject poverty suffered by many citizens, compared to global wealth being retained by a few (Ostry, Loungani and Furceri, 2016).

An alternative to the extremes of neoliberalism is a capitalism more cognisance of social democracy, where economic and social interventions pursue social justice for all citizens, capturing equal and fair wealth distribution, representational democracy, and an effective and fair welfare state. In pursuit of this, PWYP's campaign responds to globalisation's embedded conflict exposed by the resource-curse, being:

... the correlation between the abundance of oil, gas and mineral resources and low economic growth and human development in many countries. It is a critical issue as,

\footnotetext{
${ }^{3}$ Neoliberalism in this paper refers to neoliberal capitalism as characterised in footnote 2 . However, in addition to describing this phase of capitalism, the terms 'neoliberal' and 'neoliberalism' are also used to describe hegemonic discourse which carries the logic of neoliberalism in context, and to describe the contemporary pragmatic shifts in governmentality towards New Public Management (Chiapello, 2017). Chiapello (2017) offers an excellent reflection on the use and understanding of neoliberalism by critical accounting researchers and how the practice of accounting and accounting actors have contributed to neoliberalism's development.

${ }^{4}$ Civil rights are the rights of individuals to receive equal treatment, without discrimination based on gender, race, nationality, sexuality, disability and religion. Civil rights are enabled through rigorous systems of democracy, good governance, justice and due process of law and policy makers, usually supported by a existence of a fair and effective welfare state (European Parliament, 2012; Civil Rights Movement, 2016)
} 
paradoxically, two-thirds of the world's poorest people live in resource-rich developing countries (Oranje and Parham, 2009, p26).

Most resource-rich countries ${ }^{5}$ are characterised by poor democracy/governance, government corruption and may be socially divided by civil wars and human rights abuses (Oranje and Parham, 2009; Transparency International, 2011; Moffat and Haralampieva, 2014). Perceptions of government corruption in these countries are often high (Transparency International, 2011), with reports of unseen payments made by TNC's to government officials, or intermediaries, to access the right to extract natural resources (for example, see: Huffington Post and Fairfax Media, 2016). In addition, profit shifting practices of many TNCs reduces or eliminates taxation paid to local governments in respect of local corporate activity (Tax Justice Network, 2015). Accordingly, many resource-rich countries are not free to use the revenues generated from natural resources to increase the social and economic well-being of their citizens, and the secrecy surrounding corruption $^{6}$ and unethical tax practice leaves citizens impotent without information to hold their governments to account.

PWYP campaign for revenue transparency, advocating CbCR to enable citizens of resource-rich countries to access information about:

How much their government gets paid for the extraction of the counties natural resources [making it] easier to monitor how the revenue is spent. These proceeds can then serve as a basis for poverty reduction, economic growth and development (Oranje and Parham, 2009, p21).

The over-riding purpose of CbCR is emancipatory, reflecting “... actions which seek to level and disperse power, [and] ... seek[s] to instil more inclusive values than the prevailing ones" (Gallhofer and Haslam, 2003, quoting Pieterse, 1992). In particular, supporters of CbCR believe that it will:

Benefit corporate and public governance, impede corruption and tax evasion as well as accelerate growth, resource mobilization and ultimately social development and poverty reduction in resource-dependent countries (Resource Governance Index, 2010).

The struggle over IFRS8 provided PWYP with a timely window of political opportunity to influence international standard-setting. Through IASB's self-declared "open, participatory and transparent due process" (IFRS Foundation, 2012a), PWYP mobilised civil society organisations ${ }^{7}$ to respond to IASB's public Exposure Draft consultation that preceded IFRS8's adoption. Civil

\footnotetext{
${ }^{5}$ For example, Angola, Indonesia, Kazakhstan, Venezuela, Nigeria, Algeria, Sudan, Equatorial Guinea.

${ }^{6}$ Corruption and unethical tax practices are enabled by globalisation. Corruption involves secretive payments made by extractive companies to national governments to access and profit from extracting the country's natural resources. Unethical tax practice relates to questionable corporate schemes to minimise tax and move profits from high tax jurisdictions where corporate activity is undertaken, to low tax jurisdictions where tax will be paid.

${ }^{7}$ Civil Society Organisations included the Tax Justice Network, Transparency International, Revenue Watch, Tax Research UK, and many international charities, such as Save the Children, Tearfund, CAFOD, Oxfam (IASB, 2006d). Appendix 1 lists of 70 of the 79 organisations/individuals mobilised to support PWYPs comment letter campaign, as identified on IASB website (IASB, 2006b).
} 
society organisations wrote in support of PWYP's proposal, requesting that IASB mandate CbCR within IFRS8, to:

... promote greater transparency in the management of revenues paid by the oil, gas and mining industries to governments in developing or transitional countries that are resource-rich. There is a growing international consensus that enhanced transparency is essential to prevent corruption, improve governance and promote sustainable development in such countries (Tax Justice Network, 2006).

However, IFRS8 was ultimately pronounced without including CbCR, requiring only that TNC consolidated financial statements are disaggregated to give information about operating segments, which may be identified as either business or geographic segments, depending upon how segments are reported internally. Resulting IFRS8 disclosures conflate individual country activity into broad geographic regions or continents (Crawford et al., 2012). Neoliberal arguments against providing more granular geographic disclosures centred on disclosure costs and disclosing commercially sensitive information to competitors, arguably reducing potential to maximise shareholder wealth (IFRS Foundation, 2010a, Crawford et al., 2010; Ross, 2015). IFRS8's objective is “... to enable users of its financial statements to evaluate the nature and financial effects of the business activities in which it engages and the economic environments in with it operates" (IASB, 2006 - IFRS8, para 1). However, PWYP argue that financial economistic information for global capital markets "is not the only useful information available, and ... [capital providers] ... are not the only group whose requirements for information need to be taken into account" (PWYP, 2005b, p1).

In fact, IFRS8 was issued in pursuit of short-term convergence with the US Financial Accounting Standards Board (FASB), and was written in the image of the equivalent US standard, SFAS131 (FASB. 1997; IASB, 2006a, para IN2; Gallhofer and Haslam, 2007; Crawford et al., 2010). There was concern from civil society (PWYP, 2005, 2006) and the European Parliament the management approach to disaggregating TNC information mandated by IFRS8, quite contrary to $\mathrm{CbCR}$, would reduce and obfuscate information for stakeholders about the risks and drivers of international business in terms of its geographic location and impact (European Parliament, 2007). A storm of adverse publicity ensued (Neveling, 2007; Murphy, 2007; Crawford et al., 2010), inspired by PWYP's demands for CbCR (PWYP, 2005b; PWYP, 2006; Gallhofer and Haslam, 2007). There was also wide-spread disquiet from non-US constituencies about IASB's due process that enabled it to copy a US standard without giving other constituencies, for example the European Commission and national governments of EU member states, sufficient access to scrutinize the IASB-FASB proposals (Vernon, 2007; European Commission, 2010).

Consistent with a critical interpretive approach employed by authors in search of emancipatory social accounting (for example, see: Gallhofer and Haslam, 2003, 2006, 2007, 201 1, 2017; Spence, 2009; Dryzek, 2011; Jacobs, 2011; Catchpowle and Smyth, 2016; Lehman, 2017; Modell, 2017), the empirical evidence for this paper has been gathered from analysing documentary evidence, and illuminating debates, negotiations and advances by supranational organisations, during the struggle over IFRS8. This involved reviewing and interpreting narratives within: IASB staff papers; stakeholder letters received by IASB in response to consultations; and meeting minutes and webcasts from international constituencies, such as the European Commission. Articles were also sourced from newspapers, regulator reports (for example, from the US Securities \& Exchange 
Commission (SEC) and the European Commission's securities and markets agency (ESMA)) and transcripts of speeches given by key personnel with whom IASB sought to interact to achieve convergence goals. The transcripts of four interviews ${ }^{8}$ provided additional evidence of perceptions of struggle at the time IFRS8 was adopted. The interviewees were: a PWYP advocate; the Technical Director of a supra-regional professional accountancy body, representing over 20 countries; a senior civil servant of the European Commission; and the Chief Accountant of a TNC. Gathering documentary evidence from hard and soft sources about standard-setting due process has been used by other authors (for example, see Loft et al., 2006; Humphrey et al., 2009; Bengtsson, 2011; Palea, 2015) to gather "useful background knowledge" and "to gain a rich understanding of the chain of events" pertinent to the issue being researched (Bengtsson, 2011, p568).

This current paper answers calls to explore the "interrelationship of accounting and globalisation, giving some consideration to the relatively neglected dimension of accounting's location in relation to the [emancipatory] potentiality and opportunity of globalisation" (Gallhofer and Haslam, 2006, p.903), and positive potentialities of globalisation generally (Dryzek, 2011). Gallhofer and Haslam (2017) offer a reflection on the construction of emancipatory accounting over the last four decades, illuminating its relative rarity in critical accounting research. Notwithstanding this observation, academic research on accounting's emancipatory potential can be broadly categorised in three ways. First, exploring the use of contemporary and historical accounting information for social activists' argumentation in an attempt to emancipate and equalise society (for example: Gallhofer and Haslam, 2003, 2006; Catchpowle and Smyth, 2016). Second, exploring accounting interventions to raise awareness of the impact of corporate activity on civil society (Spence, 2009; Cooper and Coulson, 2014), including the creation of counter accounts $^{9}$ (Cooper et al., 2005; Denedo et al., 2017) and expanding accounting education (Ferguson et al., 2006). Third, raising the profile of ethically conflicted practice, for example tax malpractice, corruption and corporate audit, to become political issues for debate (for example: Sikka et al., 2009; Sikka, 2016; Dallyn, 2016; Finér and Ylönen, 2016). In contributing to current debates, this paper explores a fourth dimension of emancipatory accounting which illuminates PWYP's success in innovating, diffusing and instituting incremental mandatory accounting change for TNCs, thus shifting the balance of power over international accounting's development away from IASB and neoliberal hegemonic forces. This dimension diverges from Catchpowle and Smyth's (2016, p232) argument that social movements "do not have, nor ever will have, enough counter-hegemonic force to develop their own alternative accounts that will gain widespread support within capitalist social relations". But this dimension supports Chiapello's (2017, P60) optimism that social movements "campaigning for specific causes are in a situation of pragmatic experimentation and critical invention that cannot be subsumed into a simple stance on neoliberalism". Further, this research uses social movement theory to help explain how PWYP

\footnotetext{
${ }^{8}$ Semi-structured interviews were carried out in 2008 as part of a larger study (reference withheld for peer review); four were selected to review for this paper, to seek additional evidence to complement the publically available documentary evidence gathered.

9 Unlike PWYP's campaign which seeks to incrementally reform contemporary corporate reporting practice to enhance transparency, the concept counter accounting in the literature is more aligned with radical revolution (Cooper et al, 2005) and "is differentiated from other forms of external accounting due to its explicit oppositional perspective to challenge and confront dominant and unequal power relations, unacceptable political ideologies and to delegitimise corporate unsustainable practices by giving voice to oppressed groups" (Denedo et al., 2017, p2).
} 
was ultimately successful in diffusing CbCR in the EU, after initially being constrained by IASB's due process. Of interest, the critical accounting literature tends to focus on the critique of international standard-setting as being dominated by powerful, global agents, with similar neoliberal ideology, that marginalises the values of other constituencies (Loft et al., 2006; Humphrey et al., 2009; Durocher et al., 2007, Crawford et al., 2014, Chiapello and Medjad, 2009). By contrast, this paper frames its analysis "towards an accent on the positive" (Gallhofer and Haslam, 2006, p914, Gallhofer and Haslam, 2017)) and reveals PWYP to be a powerful voice giving rise to emancipatory opportunity within globalisation's context.

This paper proceeds as follows. The next section discusses globalisation's embedded conflicts, social movement theory and diffusion. This is followed by discussing IASB's due process, particularly in relation to IFRS8, and the rise of PWYP as the leading social movement campaigning for CbCR. A critical analysis of documentary evidence and semi-structured interviews is then presented, followed by concluding comments.

\section{Globalisation and accounting: embedded conflicts, social movement theory and diffusion}

\section{Globalisation's embedded conflicts}

The contextual situation of globalisation over past decades has been narrowly focused on institutionalising social structures and inter-relationships that facilitate the workings of a neoliberal form of capitalism (Chiapello, 2017). For Lehman (2005), the term 'globalisation' ${ }^{10}$ specifically refers to the "economic consequences of internationalisation" which enable "expansion of trade and commerce between countries" (p.976). Advocates of this aspect of globalisation believe it will be enabled by developing and applying international accounting (and audit) practice that supports the decision-making behaviour of [providers of finance]" (Fogarty et al., 1994p.41). ${ }^{11}$ Critics of this singular focus on supporting global neoliberalism warn of the risk of destabilising local and national communities by ignoring international business' impact on the long-term well-being of citizens (Gallhofer and Haslam, 2006; Lehman, 2009; Hopper et al., 2017).

Accounting, as a socially constructed phenomenon, will substantively reflect the needs of those who set the requirements and the extent to which accounting standard-setters take on board the views of diverse stakeholders affected by corporate activity (Young, 2003; Durocher et al., 2007; Gallhofer and Haslam, 2007, Chiapello and Medjad, 2009; Catchpowle and Smyth, 2016; Brown, 2017; Chiapello, 2017; Hopper et al., 2017). Catchpowle and Smyth (2016) explore the class nature of accounting when used to inform a local trade union dispute. Hopper et al. (2017), analysing the impact of accounting on developing countries, argue contemporary international accounting practice carries "bias to Northern ideologies and interests, not least those of [TNCs]"

\footnotetext{
${ }^{10}$ Hopper et al. (2017, p127) defines globalisation from in an economic-geography perspective, being "the growing mobility of goods, services, commodities, information, people and communications across national frontiers", and contrasts this to a neoliberal economistic view which emphasises the integration of global trade, national economies and international financial markets.

${ }^{11}$ For a critique of accounting's role in globalisation and alternative views on celebrating global difference, see Accounting Forum, Vol. 27(4), 2003, a special issue including appraisals of alternatives to globalisation from, e.g., Everett (2003), Cooper et al. (2003) and Graham and Neu (2003).
} 
with an "orientation to financial over development ends" (p125), echoing Gallhofer and Haslam's (2003, p100) observation that:

...many critical appreciations of accounting understand the practice as a capitalistic
and repressive servant of problematic [Anglo-American] hegemonic
forces...typically seen as a neutral and professional expertise.

However, conventional international accounting practice is seemingly established as a technical tool, capable of recording economic facts in a way that 'tells it like it is' (Gallhofer \& Haslam, 2007, p634). And Young (2003) discusses the rhetorical strategies captured in accounting standards that "help to construct standards as technical products and thereby also work to maintain the myth of accounting objectivity" (p621). However, several authors encourage identification, scrutiny and publicity of the social conflicts that exists within a neoliberal capitalism, to raise awareness of emancipatory accounting potentiality towards accounting praxis (Brown, 2017; Chiapello, 2017 and Gallhofer and Haslam, 2017).

Globalisation's relationship with the development of international accounting practice has enabled the construction and reproduction of a global accounting practice that reflects the ideologies of Anglo-American actors promoting the principles of neoliberalism (Gallhofer and Haslam, 2007; Spence, 2009; Palea, 2015). The UK and US professional accountancy representatives conceived the predecessor to the IASB, the International Accounting Standards Committee, in 1973 and therefore set the original social context within which to develop international accounting practice based on meeting their shared capitalistic values (Gallhofer and Haslam, 2006, 2007). Over the last four decades, IASB has become a dominant force at the heart of international accounting standard-setting with diffusion of its standards of practice attributed to large transnational audit firms and related capital market regulators (Nobes, 2014). Indeed, recently, there has been a move from national standard-setters informing development of their own standards, based on international practice, to national standards being replaced by IASB pronouncements (Nobes, 2014). Notably, IASB pronouncements attract global support from the IMF and the World Bank which have recognized them as benchmarks ${ }^{12}$ of good practice for developing and operating capital markets. International regulators such as IOSCO and the Basel Committee, and over 120 countries worldwide, require or permit IASB pronouncements for corporate reporting (IFRS Foundation, 2013c, 2015a). ${ }^{13}$ However, an accounting so constructed, risks exclusion of social-based accounting disclosures for decision-making in pursuit of societal well-being (Gallhofer and Haslam, 2007; Spence, 2009). Developed international practice, once allowed or endorsed in nation states, can therefore create tensions where conflicts arise between the "economic, political, social, cultural and spiritual dimensions of ways of life of those living" in diverse national jurisdictions, where neoliberalism may not be a prioritised value (Gallhofer et al., 2012, p.329).

\section{Social movement theory and diffusion}

\footnotetext{
${ }^{12}$ The IMF and the World Bank have substantive input into the development of international accounting and audit standards (Loft et al., 2006; Humphrey et al., 2009; IMF 2011, 2015). These bodies recognise international standards in 12 policy areas related to their work; IASB pronouncements, together with standards issued by the International Audit and Assurance Standards Board (IAASB), ostensibly contribute towards a rigorous and credible capital market infrastructure (IMF, 2011 and 2015).

${ }^{13}$ Of interest, the US only permits non-US companies to list using IFRS statements, but requires US companies to prepare financial reports based on FASB pronouncements.
} 
Globalisation's embedded conflicts provide potential to make visible all types of world-wide social relations "which link distant localities in such a way that local happenings are shaped by events occurring miles away and vice versa" (della Porta and Kriesi, 2009 - quoting Giddens, 1990). Such conflicts create opportunities that can be exploited by social movement agency to lever institutional change (Thornton and Ocasio, 1999; Roulet, 2014; Nielsen and Lockwood, 2015). For PWYP, the embedded institutional conflict is of an ethical nature (Nielson and Lockwood, 2015), where the work of, and relationship between, TNC and local governments sanction the resource-curse (IMF, 2014).

The emergence of international, supra-state organisations provides new opportunities for social movements to engage at the trans-national level and influence universal policy development implementable at the local level (della Porta and Kreisi, 2009; Marks and McAdam, 2009; Passy, 2009; Schneiberg and Lounsbury, 2009). ${ }^{14}$ Such transnational social movements are a type of international NGO, campaigning on behalf of civil society about a specific grievance. In recent decades, they have been responsible for pursuing and diffusing new institutional norms that challenge prevailing logics, by engaging in the political opportunity structures of international policy makers. Indeed, the form of social movement action is shaped by the prevailing institutional environment, with "the narrowest of institutional reform efforts at one pole and revolution on the other" (Marks and McAdam, 2009, p101). Where the social movements targets a policy maker which grants access to its policy making process, the tactics deployed by the social movement attempt to mobilise incremental institutional change through available political opportunity structures (Marks and McAdam, 2009; Shneiberg and Lounsbury, 2009). Prior research demonstrates that International Governmental Organisation whose mission is on social development, such as the UN, tend to facilitate social movement demands (Passy, 2009). By contrast, international finance institutions such as the IMF and the World Bank, which have traditionally supported neoliberal-capitalistic principles in pursuit of economic development, are less inclined to be receptive to by social movement action (della Porta et al., 2009).

Social movements use a repertoire of tactics including "contestation, collective action, framing of arguments and self-conscious mobilisation of strategic action" (Schneiberg and Lounsbury, 2009, p651) to drive change. The nature and extent of social movement agency to diffuse advocated practice will be influenced by planned events arising in the institutional environment, such as IASB's proposal to adopt IFRS8 which provided PWYP with the opportunity to pursue its campaign for $\mathrm{CbCR}$ at the international level. Additionally, unplanned exogenous shocks, for example the $2007 / 8$ GFC, will likely impact on a social movement's tactics by enhancing societal awareness of embedded institutional conflicts and their global repercussions (Thornton and Ocasio, 2008; Roulet, 2014). Indeed, Botzem, (2014) argues that the financial crisis has reinvigorated and re-politicised transnational accounting regulation, recognising a need for a more coordinated, inclusive and transparent global governance. In addition, the media plays a crucial role in publicising inequalities arising from a capitalistic culture that rewards profit seeking behaviour and simultaneously erodes civil rights (Roulet, 2014), and advances inequalities through tax avoidance and corruption (Dallyn, 2016; Islam et al., 2016). Interestingly, Gallhofer and

\footnotetext{
${ }^{14}$ Prior to globalisation, social movement agency had limited effect on policy development, particularly in nondemocratic regimes (Passy, 2009).
} 
Haslam's (2003) interpretation ${ }^{15}$ of Bentham's writings on the emancipatory potential of accounting, also note that publicity is a key mechanism "...to engender openness and transparency in the public realm ... to bring about social happiness" (p43).

In this paper, PWYP is conceptualised as a social movement, attempting to diffuse CbCR through active engagement with the political opportunity available in IASB's due process. ${ }^{16}$ Diffusion conceptualises the sequential process ${ }^{17}$ by which a "model, idea or practice, once created" (Sahlin and Wedlin, 2008, p224) is communicated over time to members in a social network (Rogers, 1995, 2003; Abrahamson, 2011), from initial discovery to widespread implementation. The collaboration between leaders of a new practice and targeted propagators is fundamental for starting the diffusion of new knowledge and persuading other actors to adopt the practice (Abrahamson and Rosenkopf, 1997; Bjornenak, 1997; Abrahamson, 2011). Using this framework: PWYP is leading diffusion of the new practice of CbCR, which PWYP originally innovated through hiring an accounting expert (PWYP, 2005); IASB is the target of PWYP's agency, whereby PWYP is trying to persuade IASB to adopt and propagate CbCR; and the other actors are those in IASB's network, being international financial regulators and national accounting standard-setters who accept IASB standards.

\section{Globalisation's political opportunity in IASB's due process}

Political opportunity structures have three broad dimensions that enable or constrain social movement influence: First, existing institutional structures determine the degree of access to the policy maker. Second, the policy maker's prevailing strategies to negotiate with social movements (or not) will determine the extent to which social movements are included in the policy making process. Third, the balance of power between the social movement, the policy maker and other actors in the institutional field will determine the extent to which social movements are enabled or constrained by establishing alliances and recruiting influential allies (Kreisi et al, 1995 - as cited in Schneiberg and Lounsbury, 2008; Passy et al, 2009).

The mission of the IFRS Foundation and its technical board, the IASB, is to:

...develop International Financial Reporting Standards (IFRS) that bring transparency, accountability and efficiency to financial markets around the world.

\footnotetext{
${ }^{15}$ There is an alternative, contested (Gallhofer and Haslam, 2003) interpretation of Bentham's writings being that publicity was primarily to motivate the poor to take responsibility for themselves (Roberts, 1979). Bentham developed the idea of the panopticon prison for the poor (Bahmueller, 1981), which enabled observation around the clock; interpreted through a Foucauldian perspective as repressive surveillance to modify the behaviour of those incarcerated. However, Bentham also proposed that publicity, exposing the behaviour of prison wardens towards those incarcerated, would be a key mechanism of transparency and accountability for ensuring the humane treatment of the imprisoned (SEOP, 2015).

${ }^{16}$ IASB does not have sovereign coercive power. Nevertheless, it does have political power through its established position to develop standards and obtain support for the implementation of these standards from international financial organisations and its network of national accounting standard setters and regulators in over 120 countries across the globe.

${ }^{17}$ In the diffusion process there are five sequential stages: knowledge, persuasion, decision, implementation and confirmation (Rogers, 2003). Typically, this process is characterized by uncertainty (Brancheau and Wetherbe, 1990) that agents involved in the innovation can attempt to manage.
} 


\section{Our work serves the public interest by fostering trust, growth and long-term financial stability in the global economy (IFRS Foundation, 2015a).}

The opportunity to influence development of these standards is offered through IASB's declared "thorough, open, participatory and transparent due process" that includes engagement and collaboration with diverse stakeholders and standard-setters around the world (IFRS Foundation, 2013d). IASB's due process, leading to the adoption of an international standard, includes: research prior to the possible publication of a Discussion Paper with invitations to comment; production of an Exposure Draft (ED) for public consultation; analysis of comment letters received in response to the ED consultation; and finally the publication of the mandatory standard with a Basis for Conclusions explaining the IASB's deliberations and analysis (IFRS Foundation, 2013d). For some projects, IASB will constitute an advisory committee to guide the proposed development of a new standard; otherwise IASB will undertake this work itself.

However, recent literature criticises IASB's due process as being undemocratic, highly political, non-transparent, favouring those countries where highly developed capital markets operate, and where capital market regulators and large professional firms have a vested interest in pursuing the goals of globalisation (Perry and Nolke, 2006; Arnold, 2009; Suddaby et al., 2007). Several commentators have argued that IASB $^{18}$ is overly influenced by the big international accounting firms and international financial market regulators (Whittington, 2005; Loft et al., 2006; Humphrey et al., 2009; Arnold, 2009) that are equipped with the time, skill and expertise to participate in IASB consultations (Chiapello and Medjad, 2009; Durocher et al., 2007). Indeed, such organisations can purchase "formal channels of influence, such as being co-opted into IASB's various advisory boards" (Martinez-Diaz, 2005 - as cited in Bengtsson, 2011, p.569) and by funding the activities of the IASB (Gallhofer and Haslam, 2007; Larson and Kenny, 2011). There is also much concern about the lack of constituent participation in the standard-setting process, particularly from users of financial market information (Durocher et al., 2007; European Parliament, 2007; Chiapello and Medjad, 2009). Similarly, narrow stakeholder participation, from few geographic locations, has been observed, which arguably undermines the IASB's legitimacy to serve the public interest and in promote itself as the accepted global standard-setter (Larson, 2007; Burlaud and Colasse, 2011; Larson and Herz, 2013) and in the public interest (Gallhofer and Haslam, 2007). Further literature highlights that global acceptance of international practice, and the process of setting international standards, is not whole-hearted. For example, Bengtsson (2011) investigates "how the EU sought to gain control over IASB and how [the IASB] responded to limit political influence" (p.567). Similarly, Crawford et al. (2014) show how the EU implemented its new comitology ${ }^{19}$ process in 2007 to reject [initially] IFRS8 for endorsement, in an attempt to regain some control over the IASB's standard-setting process. In his interrogation of IASB's influence over fair-value accounting, Palea $(2015, \mathrm{p} 11)$ warns that caution should be

\footnotetext{
${ }^{18}$ And the International Federaton of Accountants (IFAC), which is responsible for setting international standards for auditing, ethics, public sector accounting and professional accountancy education (IFAC, 2015a). In addition, professional accountancy bodies who are members of IFAC are obligated to comply with IFAC and IASB standards and are required to disclose the extent of compliance as part of the IFAC compliance programme together with an action plan to achieve full compliance (IFAC, 2015b).

${ }^{19}$ Comitology is the process undertaken by the European Commission to modify of adjust EU law. In the context of IFRS8, comitology procedures were implemented after IFRS8 was rejected by the European Parliament for endorsement under Regulation (EC) No 1606/2002 (European Parliament, 2002).
} 
exercised in accounting standard-setting and endorsement “... to prevent the European institutions from being influenced by interest groups".

\section{Location: The IFRS8 affair and PWYP}

IFRS8 - debate, disruption and tension

In 2002, IASB and the US FASB entered into a formal international alliance, signing the Norwalk Agreement committing to:

The development of high-quality compatible accounting standards that could be used for both domestic and cross-border financial reporting (Norwalk Agreement, 2002).

In 2006, the IASB-FASB alliance formalised segmental reporting for short-term convergence (IASB/FASB, 2006) and issued ED8 'Operating segments'. In line with due process (IFRS Foundation, 2013d), a three month open consultation ensued. This journey, from alliance creation to exposure draft publication, illuminates the political practice of putting in place material structures (being the proposed accounting standard) to replicate and sustain the embedded ideology of the privileged alliances and exclude other constituencies from the process (Gallhofer and Haslam, 2007; Spence, 2009; Palea, 2015). Such a process ultimately works to meet the pragmatic needs of IASB's convergence mission without disrupting FASB's territorial accounting practice. After analysing the comment letter responses to the consultation, IASB adopted IFRS8 in 2006, written in the image of the FASB's SFAS131 (IASB, 2006a, para IN2), which became effective for accounting periods starting on or after 1 January $2009 .{ }^{20}$

The struggle over IFRS8 provides a rich source of material to explore emancipatory opportunity in the context of globalisation for two reasons: the highly publicised controversy relating to its potential accounting outcome and the due process by which it came to be adopted. IFRS8's novel 'management approach' (IASB, 2006a, BC9-BC17) requires operating segments to be identified and disclosed as if seen "through the eyes of management" (IASB, 2006a, BC60), introducing the US concept of the 'chief operating decision maker', potentially reducing or removing geographical segments and expressing disaggregated information using non-IFRS measures (IASB, 2006a, BC; European Parliament, 2007; European Commission, 2007; Veron, 2007; Crawford et al., 2010; ESMA, 2011; FRRP, 2010). In relation to due process, IFRS8 was the first standard to copy a US standard so comprehensively. IASB also determined that PWYP demands for CbCR should not be considered, therefore excluded 79 PWYP coalition letters (See Appendix 1) received in response to ED8, analysing only the remaining 102 letters from other stakeholders to support IFRS8's adoption (IASB, 2006a, para BC50). Additionally, IFRS8 was the first standard to be vetoed by the European Parliament, who required the European Commission to carry out a Europe-specific potential effects assessment before authorising endorsement (European Commission, 2007; Crawford et al., 2010 and 2014). Finally, IFRS8 provided the instrument around which IASB elaborated its due process to include a post-implementation review, and implemented this review for the first time (IFRS Foundation, 2013a).

\footnotetext{
${ }^{20}$ This standard replaced International Accounting Standard (IAS) 14 (Revised) and copied, except for minor differences, with its US counterpart Statement of Financial Accounting Standard (SFAS) 131 (IASB, 2006a, para IN3)
} 


\section{Publish what you pay, country-by-country reporting, contestation and framing}

PWYP was launched in 2002 with 6 London-based founding members, calling for an end to corruption in the extractive sector, to be facilitated by developing transparency and anti-corruption regulation $^{21,22}$ Today PWYP is a global coalition of $>800$ civil society organisations "united in their call for an open and accountable extractive sector" (PWYP, 2015c). France and CongoBrazzaville formed the first two national coalitions in 2003, rising to 24 (2008), 36 (2014) and 41 (2017) (Oranje and Parham, 2009; PWYP, 2017a) (Table 1, Panel A). Members are mostly national/local organisations operating in human rights, environmental and transparency/anticorruption sectors, and mainly structured as autonomous national coalitions (Table 1, Panel B). ${ }^{23,24}$ PWYP membership requires adherence to PWYP's principles and standards, which include: constructive engagement with key stakeholders; information sharing across coalitions; embracing partnership and collaboration to leverage campaign goals; and coordinating with each other and with PWYP at the global level to ensure coherence and harmonisation (PWYP, 2017c).

\section{Insert Table 1 about here}

PWYP contests the resource-curse and attempts to mobilise CbCR for TNC's operating in the extractive industries in pursuit of:

\section{a world where all citizens benefit from their natural resources, today and tomorrow ... for a more transparent and accountable extractive sector, that enables citizens to have a say over whether their resources are extracted, how they are extracted and how their extractive revenues are spent. (PWYP Objectives, 2015).}

Its key objective is to lobby for financial transparency, advocating mandatory $\mathrm{CbCR}$ which demands that TNCs publish:

... a profit and loss account and limited balance sheet and cash flow information for almost every jurisdiction in which they trade (Murphy, 2012, p.6).

\footnotetext{
${ }^{21}$ CAFOD, Global Witness, Open Society Foundation, OXFAM, Save the Children and Transparency International. 22 In 2002, PWYP was also successful in forming an alliance with the Extractive Industries Transparency Initiative (EITI) as acknowledged: "The EITI would not exist were in not for PWYP. The EITI is largely a quasi-multi-lateral international response to civil society campaigning under the PWYP umbrella" (Moberg, 2012). The EITI is a voluntary standard, revised in 2013, that only becomes mandatory if a national government chooses to endorse it; precise national rules are then determined to require extractive companies to report payments to the government and vice versa.

${ }^{23}$ Forming a national coalition entails additional governance requirements, including a MoU, strategic plan for fundraising, financial management and information sharing, as well as a national coordinator devoted to coordinating campaign activities and coalition members. Generally this means that national coalition members are a little more organised and meet more frequently.

${ }^{24}$ From launching in 2002, PWYP operated under the governance structure of the Open Society Foundation (OSF), until 2015 when it became independent. PWYP now has its own secretariat at the global level and is governed by a Global Council and the PWYP board, with the former having strategic responsibility and the latter being responsible for protecting and advancing PWYP objectives. The Global Council is accountable to coalition representatives that assemble every three years to review and develop strategy.
} 
PWYP has framed their campaign for CbCR to resonate with IASB's declared objective to serve the public interest for the benefit of capital markets (PWYP, 2005b; Gallhofer and Haslam, 2007), arguing that public interest will be served if the needs of professional and independent providers of capital are met, as well as all the affected stakeholders of a company who have no legal right to receive financial statements (PWYP, 2015b). Additionally, PWYP argue that enhanced credibility and transparency of $\mathrm{CbCR}$ would provide commercial benefits to reporting companies by demonstrating their commitment to society and investors "wherever they might be located" and reducing reputational risk (PWYP, 2015b, p11).

By the time of IFRS8's publication in 2006, PWYP was "backed by a coalition of over 300 civil society organisations from more than 50 countries worldwide" (ACIDH, 2006). However, the nature and objective of IASB's and PWYP's approach to disaggregating TNC consolidated disclosures are ideologically different. PWYP's public interest objective prioritises providing critical economic information to enable local communities, individuals and stakeholders, who are directly affected by TNC activities, to make informed decisions about national risks that potentially affect their own economic and social well-being. These local communities and individuals, constitute diverse groups of stakeholders, for example management, employees, national regulators, national trade suppliers and customers. Each group has a different, often complex and long-term dependency relationship with a TNC operating in their country, usually characterised by a close, personal and physical proximity, from which it may be difficult to disengage (PWYP, 2005). This contrasts with capital market stakeholders who often have a remote relationship with a given TNC, and their related capital investment decisions are easy to implement or dismantle. Table 2-Panel A compares the nature, objective and ideology of the IASB to PWYP; panels $\mathrm{B}$ and $\mathrm{C}$ compare the accounting approach to disaggregation and principal stakeholders, respectively.

The campaign for $\mathrm{CbCR}$ is emancipatory, seeking to provide information that will enable all citizens, including capital market investors, to make decisions about local natural resources, for the benefit everyone and "not just the few [investors]" (PWYP, 2015a). Panel D of Table 2 categorises CbCR's outcome as reflective of a differentiated universalism, where universalism advocates free and equal rights for all citizens, enabled by meeting the differentiated needs of particular groups in society (Lister, 1998; Gallhofer and Haslam, 2007; Gallhofer et al, 2015).

\section{Insert Table 2 about here}

CbCR determines the countries ${ }^{25}$ in which TNC activities occur as individual reportable segments. For each country, segmental line-item disclosures are prescribed, with particular emphasis on disclosing information about local tax charges, obligations and payments to national governments. $\mathrm{CbCR}$ is also advocated by the Tax Justice Network, Eurodad and Transparency International ${ }^{26}$ as

${ }^{25}$ The EU Accounting and Transparency directives also require project-by-project level reporting (Chatzivgeri et al., 2017)

${ }^{26}$ The Tax Justice Network is a non-governmental organisation of researchers, analysts and advocates promoting tax justice where companies pay the correct amount of tax at the right time in the country where the economic activity that generated taxable profits occurred (Tax Justice Network, 2017); Eurodad is a network of almost 50 civil society organisations across Europe campaigning to eradicate poverty and secure human rights through sustainable financial and economic systems (Eurodad, 2016). Transparency International is a global civil society 
a transparency tool in the fight against tax injustice. Table 2 compares the disclosure requirements as proposed in ED8 with those of CbCR proposals of PWYP; as can be seen, the latter are extensive by comparison.

Insert Table 3 about here

\section{Realising positive potentiality and opportunity through struggle: the case of IFRS8}

\subsection{Tensions rising over the development and adoption of IF RS8 in 2006}

\section{Targeting IASB and IASB resisting PWYP agency}

Recognising the global reach of IFRS, PWYP attempted to mobilise accounting change by challenging IASB to amend ED8, its justification being that:

Using international accounting standards as the vehicle for this type of disclosure [CBCR] would be the best way to create a level playing field for companies ... as they [IFRS] are applied automatically in more than 110 countries (Resource Governance, 2010).

However, IABS's response was controversial for two reasons First, IASB used power over its due process to prioritise its FASB convergence priority by issuing ED8 in the image of the related US standard; other constituencies consequently perceived their particular needs being marginalised. Second, excluding the views expressed in 79 PWYP coalition letters that were received in response to ED8's consultation, meant that almost half of the remaining letters analysed by IASB were from preparers (Crawford et al., 2010), who were generally in favour of proposed requirements, for example:

As a preparer under both, IFRS and USGAAP, we strongly support the board's intention to achieve convergence with USGAAP by adopting the guidelines set out in SFAS131 (Allianz Aktiengesellschaft, 2006 - CL164).

The decision to issue ED8 raised tension relating to constituency access to IASB's policy making process with Veron $(2007, \mathrm{p} 1)$ noting that "in spite of widespread negative sentiment about [proposed changes to the existing segmental reporting requirements]", IASB published IFRS8. In his address to the Economic and Monetary Affairs (ECON) Committee of the European Parliament in 2007, he exclaimed:

Unlike for some other convergence projects which give rise to the drafting of new standards by the IASB and FASB jointly, the Memorandum of Understanding indicated that the convergence of segment reporting would be attained by the alignment of the

movement campaigning for a world free of corruption (Transparency International, 2017). The detail of CbCR proposed by each organisation are slightly different. 
IFRS on existing USGAAP provisions. Thus, ED8 was quickly released as a nearly identical standard to the existing SFAS131.... It is to be noted that the February 2006 convergence Memorandum of Understanding, which has been the dominant driver of the IASB's agenda since then, has itself been submitted to no consultation by stakeholders (Veron, 2007, p6).

IASB excluded non-US constituents by neither issuing a discussion paper nor constituting an advisory committee prior to ED8. In fact, IASB argued that neither were necessary because segmental reporting was not contentious, and the equivalent US standard had operated well since 1997, elaborating that convergence with FASB:

... is being conducted by the IASB only. This project does not have a working group because it is part of the short-term convergence project.... A discussion paper was not considered necessary for this project because the objective of the project is to reduce differences in segment reporting between IFRSs and United States generally accepted accounting principles (IFRS Foundation, 2006).

IASB, ultimately concluded there was overall support for the proposed new requirements and adopted IFRS8 in 2006. The Basis for Conclusions to IFRS8 showed that IASB drew on prior US academic research which highlighted a positive decision-usefulness impact on moving to SFAS131 in the US. However, using this research to justify IFRS8's adoption is problematic since the predecessor standards to IFRS8 and SFAS131 (IAS14 and SFAS14, respectively) had significantly different reporting requirements. Indeed, in interview, the PWYP advocate expressed outrage that this research was used to validate IASB's decision, stating:

Why did we adopt an American standard which was already proven not to work, you know, it is a politically adopted standard, there was no other reason why we brought into the IASB a standard which had already been shown by various people's work to actually have reduced standards of governance, to have reduced the quality of decision making, to have a reduced shareholder return, and to have diversified approach without necessarily earning any benefit within US corporations.

Ultimately, should the US commit to requiring IASB pronouncements for their capital market in the future, IFRS8 will meet their pragmatic needs with minimal disruption to existing US accounting disclosures. Interestingly, shortly after IFRS8 was adopted, the SEC passed a motion to allow filing of IFRS accounts for non-US companies, without requiring reconciliation USGAAP. Additionally, SEC announced that they would be in a position by 2011 to decide on how to apply IFRS for US issuers and mooted possible IFRS compliance by 2014 (SEC, 2008).

The power of IASB to choose to ally with the FASB and exclude other constituencies from collective policy making appears to contradict the declared purpose IASB's due process, where:

... due process requirements are built on the principles of transparency, full and fair consultation-considering the perspectives of those affected by IFRSs globally (IFRS Foundation, 2013d, para 3.1(b), p8). 
Consequently, during the IFRS8 affair, PWYP and European constituencies became more active in their protest, exposing institutional conflict still further, between pursuing IASB-FASB ideology at the expense of developing financial reporting information to [also] meet the needs of national citizens. Even a financial statement preparer who responded to ED8 stated:

... we are of the opinion that convergence should not be the principle motivation ... [the previous standard] provides far more relevant, reliable and useful [information] (Anglo Platinum, 2006, CL 63).

Echoed in interview with the technical director of a supra-regional professional accountancy organisation stated:

... often [stakeholders] feel it's not good that just because of the convergence [programme], and that the American standards and the international [standards] have to become closer, we all have to go to a different standard just because there is a problem in the States [not adopting IFRS], ... [IASB] standards are not broken but they apparently need to be repaired for other [convergence] reasons.

IASB's decision to adopt IFRS8 created tension at the European Commission in advance of the European Parliament's endorsement of IFRS8. During interview, the European Commission civil servant exclaimed:

... why did the IASB not design a standard which ... also address[ed] European needs, and in view of the comments made by Publish What You Pay coalition ... of course the parliament was very sensitive ... and therefore parliament said we have to have a second look because we believe ... introducing a management approach for that sensitive subject, and knowing the concerns expressed, we don't believe [IFRS8] should be adopted just like that.

In 2007, IFRS 8 consequently became the first international accounting standard to be vetoed by the European Parliament after the parliament implemented newly constituted comitology procedures that enabled it to reject the European Commission's recommendation to endorse IFRS8 (Crawford et al., 2010). The European Parliament challenged IASB, both in terms of IFRS8's potential accounting outcome and IASB's due process enabling it to set standards in a European context (European Commission, 2007). In making their decision, the European Parliament stipulated:

... International accounting standards can only be adopted if ... they are conducive to the European public good and they meet the criteria of understandability, relevance, reliability and comparability required of the financial information needed for making economic decisions and assessing the stewardship of management (European Parliament, 2002, Article 3, para 2). 
Implicitly therefore, the European public good concept should be considered separately from the global public interest articulated in IASB's objective. Within the European context, stewardship ${ }^{27}$ of resources is clearly important, and the Lisbon Treaty stipulates that European sustainable development must balance economic growth with social justice (Palea, 2015).

The European Parliament did ultimately endorse IFRS8. However, it expressed concern about "incorporating US SFAS131 into EU law" (European Parliament, 2007), and was unequivocal in articulating "Regrets" and "Reservations" about: FASB convergence;IASB due process; and the potential impact of IFRS8 on reducing geographical segmental information (European Parliament, 2007). The endorsement instrument also specifically expressed the European Parliament's support for CbCR and "asks the [European] Commission to report back to Parliament on the outcome of the discussion with the IASB" in this respect.

\section{Emerging emancipatory moments from conflict}

It is important to recall the reason behind PWYP attempting to influence IASB's standard for disaggregated disclosures by TNCs, being:

When a country grants a company the right to extract its natural resources, it is a big deal. When the resource is depleted, it is gone forever; a government can only spend the money received once; and we know that all too often, that money does not end up benefiting the largely poor population through, say, better schools, or new hospitals. Investors and citizens need to know what payments governments are receiving from these companies so that they can follow the money and improve accountability in a sector which is historically characterised by opacity (Williams, 2015).

PWYP had urged their member organisations to send a comment letter in response to ED8's consultation, using a letter-template of similar wording to PWYP's own comment letter response. In these comment letters, PWYP members called for transparent disclosure by international corporations operating in developing/transitional resource-rich countries for:

...country-by-country disclosure requirements to be incorporated into international standards so that information on payments to individual governments is available [for] decision-useful information about the scale and location ... of reporting entities' international activities (ACIHD, 2006 - CL43).

Christian Aid (2006, CL146) argued that CbCR “could be disclosed at relatively little cost because it should all already be available in the companies' internal accounts". Resource governance (2015) emphasised the criticality for CbCR "to combat corruption and improve accountability in some of the poorest, yet most resource-rich countries ${ }^{28}$ in the world". However, IASB's exclusion

\footnotetext{
${ }^{27}$ At the time of writing, IASB is consulting on its ED Conceptual Framework, to give stewardship more emphasis in international financial reporting (IFRS Foundation, 2010b, 2015b).

${ }^{28}$ For example, Angola has the world's highest child mortality rate, but is oil-rich, and the Democratic Republic of Congo has vast mineral resources but is at the bottom of the United Nations development index (Resource Governance, 2015)
} 
of 79 such letters from their analysis, clearly frustrated the PWYP advocate interviewee, who exclaimed:

I don't see how you can actually treat them all [79 comment letters] as one... even if they are similar because those people chose consciously to support an issue. Now they may not have had the technical ability to re-write that letter, but they sure as heck understood why they were sending it in. There isn't a person I think who sent a letter in who was actually doing it because 'Oh there's a round robin and please do it'.

However, emancipatory moments (albeit small), began to flicker. First, IASB proactively suggested that PWYP sought to influence TNC accounting by forming alliances with other supranational organisations, advising that:

...such issues [CbCR] merit further discussion with bodies that are currently engaged in similar issues, for example the United Nations, International Public Sector Accounting Standards Board, International Monetary Fund, World Bank, regional development banks and Financial Stability Forum (IABS, 2006, para BC50).

This suggests potentiality for a shift away from the IASB-FASB dominant influence over TNC financial reporting. ${ }^{29}$ Second, in 2007, IASB amended its due process (IFRS Foundation, 2011) to include a post-implementation review "of each new IFRS or major amendment" two years after the implementation of new IFRS requirements (IFRS Foundation, 2013a, p32). The purpose being to: assess the effects of any new requirement on investors, preparers and auditors; re-visit contentious debates during the standard's development; and identify unexpected implementation problems and/or costs. Although targeted at a narrow group of constituents, this amendment to due process gives further opportunity for interested parties to contribute to maintaining or amending international standards after implementation.

\subsection{Implementation and post-implementation review of IF RS8}

In 2012, IFRS 8 became the first standard subject to IASB's post-implementation review, involving two stages: (i) setting the scope of the review and 'Request for Information' questions for consultation; and (ii) analysing information gathered (IFRS Foundation, 2013d, para 6.52-6.54). During this second stage, IASB has the option to gather additional evidence from: reviewing academic literature and other relevant research; conducting outreach events with "relevant parties"; and/or analysing financial statement disclosures (IFRS Foundation, 2013d, para 6.60).

Although the post-implementation review stipulates that the original motivation and adoption of an implemented standard cannot be reversed, which means that CbCR could not be mobilised through this elaborated process, the review does offer opportunity for interested stakeholders to suggest potential amendments. For example, IASB considered recommendations from bodies such

\footnotetext{
${ }^{29}$ IASB also committed to meet with PWYP representatives to discuss CbCR in relation to potential developments of IFRS6 - Extractive Activities, symbolising a willingness to include PWYP in development. However, IASB later concluded that the needs of PWYP and capital market investors were dissimilar and IFRS6 development has since been suspended (IFRS Foundation, 2010a).
} 
as ESMA ${ }^{30}$ to amend IFRS8 (IASB Update, September 2011). Specifically, ESMA (2011) reported the findings of their own IFRS8 implementation review and asked IASB to amend the standard to clarify "what is meant by the term 'chief operating decision maker' [and] the application of aggregation criteria" ( $\mathrm{p} 4){ }^{31}$ Second, in addition to holding internal discussions, IASB also "held consultations on [how to develop the review] process with a broad range of the IASB's consultative bodies including national standard-setters, EFRAG and capital market analysts" (IFRS Foundation, 2012b, para 18). Subsequently, IASB noted that they had amended the postimplementation review process to reflect the desires of this wider stakeholder group, most evidently from EFRAG, stating:

We consulted widely while we were developing the [review] methodology. ... As a result, we introduced a public consultation step [Request for Information] in the early part of the review process to provide a more open and transparent process ... [and to enable to undertake] a broader review of the standard (IFRS Foundation, 2013a, p30).

Evidently, IASB indicated willingness to engage with constituencies outside of the FASB, forming new relationships that could potentially shape international standard-setting and accounting. And further advances to democratic standard-setting are noteworthy in the developed postimplementation review process. At the time of IFRS8's adoption, the European Parliament endorsement instrument bemoaned the fact that "the interests of users as well as the needs of small and medium-sized companies" had not been adequately represented in the development of IFRS8 (European Parliament, 2007). As part of the post-implementation review, IASB attempted to mitigate against these concerns when selecting audiences for over 60 outreach events that it held across the world; more than half of these events were targeted at European audiences (IFRS Foundation, 2013a). However, 17 outreach events were "solely with investors" (p14) and IASB did not actively seek engagement with stakeholders protesting against the resource-curse. In addition, IASB specifically sourced non-US research to be considered during the postimplementation review when seeking evidence of how IFRS8 was working in practice at the national level.

The post-implementation review evidence gathered returned concerns persisting since the consultation over ED8, for example:

... many investors think that non-IFRS measures can be confusing or misleading [and] some preparers also do not think that using non-IFRS measures is helpful (IFRS Foundation, 2013b, para 77).

Additionally, participants in the post-implementation review reasserted concern over the understandability of concept of the chief operating decision maker and complexity of aggregation

\footnotetext{
${ }^{30}$ ESMA - is the European Securities and Markets Authority. It advises the European Commission; its mission is to enhance the protection of investors and reinforce stable and well-functioning financial markets in the EU.

${ }^{31}$ IASB initially decided that consideration of the chief operating decision maker was not necessary (IASB Update, November 2011), and conceded to "... proceed with the proposed amendment to [clarifying aggregation criteria] of IFRS8" (IFRS Foundation, 2012c - Agenda paper 10A, p17). In 2015, IASB committed to amend IFRS8 to require that the individual or function of the chief operating decision maker makes operating decisions, and that the person or function is disclosed (IASB, 2015).
} 
guidance for identifying segments (IFRS Foundation, 2013a). IASB concluded ${ }^{32}$ from its analysis that:

We have enough information to prepare a preliminary effects analysis, including staff recommendations for which agenda proposals should be prepared (IFRS Foundation, 2013b, para 185).

Ultimately, and somewhat surprisingly, despite concerns raised at: (i) the time of IFRS8's adoption; (ii) during the standard's implementation (ESMA, 2011; FRRP, 2010; Crawford et al., 2012), and (iii) in submissions to the post-implementation review (IFRS Foundation, 2012 and 2013 staff papers), IASB concluded that there was no need to amend IFRS8. Instead, IASB decided after the post-implementation review of IFRS8 that "the standard achieved its objectives and improved financial reporting" (IFRS Foundation, 2013a), stating that:

... we do not think that these concerns warrant a revision of the principles on which the standard is based, because evidence provided to us does not suggest that there are any significant failings in the standard (IFRS Foundation, 2013a, p6).

In coming to this conclusion, IASB stated "that there are some issues that could be considered for improvement to IFRS8" (IFRS Foundation, 2013a, p6), but that any such proposed amendments "should include active liaison with the FASB" (p8). Arguably, this persistent focus on meeting IASB-FASB alliance needs, perpetuated standard-setting for capital markets within the "accounting-globalisation interrelation" (Gallhofer and Haslam, 2006, p915). However, in the following section, evidence is presented of the emergence of new influential alliances and coalitions, capable of effecting accounting change globally, in the interests of global civil society. Such emancipatory development is undoubtedly related to the publicity created by the PWYP campaign during the IFRS 8 affair. As observed by the Chief Accountant of a TNC in reflecting on why IFRS 8 became the subject of global debate:

There were some [civil society] pressure groups and I think they were even in the UK which is a bit embarrassing. That having had their say on the IASB consultation process [over ED8] decided to make some noise and, you know, there's the theory that various groups in the EU ... are looking for reasons to have a go at bringing down the IASB and this was brought into that debate.

\subsection{Shifting alliances and targeting other political opportunity}

Disentanglement of IASB-FASB alliance

\footnotetext{
${ }^{32}$ However in justifying this position, it should be noted that IASB developed its post-implementation review process to conform to a similar process developed by FASB to review SFAS131 (IFRS Foundation, 2012c). Also, IASB sought to justify ESMA's proposed amendment in respect of segment aggregation, by selecting comparable issues raised by SEC shortly after SFAS131 was introduced in the US, stating “... the IASB learned that the [aggregation] concern raised by [ESMA] had been shared by some staff at the SEC in the US (IFRS Foundation, 2012c, staff paper 10A)".
} 
Around 2008/2009, following IFRS8's adoption and SEC's stated aspiration to decide in 2011 on whether to allow IFRS for US companies by 2014 (SEC, 2008), the IASB-FASB alliance started to disentangle. The alliance had agreed ambitious goals in 2006 to converge existing standards and coordinate future work programmes to gain and maintain compatibility (IASB/FASB, 2006). However, this agreement became politically unacceptable in the aftermath of the GFC. Specifically, political pressure mounted from the newly constituted Obama presidency to reform domestic financial markets (US Treasury, 2009). ${ }^{33}$

New SEC and FASB leadership responded with strategic objectives to future-proof against crisis, declaring priority towards: US-investor protection; FASB retaining control of US accounting standards; and ensuring financial reporting enforcement was not offshored (SEC, 2009; FAF, 2010; SEC, 2014). The then FASB Chair emphasised re-localising accounting standard-setting “... to strive to take care of business at home by responding on a timely basis to reporting issues in our [US] system...", and highlighted that convergence with IASB would not be easy (Herz, 2009). The threat to international convergence was noted by accounting profession actors, articulating:

The global financial crisis is having an enormous impact on the effort to standardise accounting rules worldwide. Political pressure on the IASB and the USFASB is encouraging both bodies to publish one-off changes to accounting rules that may show short-term action in the face of economic downturn, but are likely to make it harder to bring the two systems into conformity (Deloitte, 2009).

A public row between FASB and IASB was reported in 2012 as "two blows against accounting convergence" (Sawers, 2012). First, SEC failed to opine about US issuers filing IFRS-accounts, but instead issued a report (SEC, 2012) that was criticised as being " 137 pages of reasons why the SEC doesn't need to make a decision [on IFRS adoptions]" (Sawers, 2012). Second, a 'spat' between FASB and IASB ensued over the issue of convergence, when the chair of IASB, Hans Hoogervorst (quoted in Sawers, 2012), complained about his FASB counterpart:

...if you go to your constituents with the message "oh, we're so unsure, we're so unsure", then yes you're going to get a lot of additional confusion [about convergence]. I think it is deeply embarrassing.

And he went on to say that IASB would focus on providing:

... adequate support to the majority of the G20 who have already adopted IFRS and supporting those other jurisdictions to complete their own transitions.

Confirming this deterioration in IASB-FASB's specific relationship, the FASB chair remained positive towards global convergence, but by broadening participation by:

\footnotetext{
33 The US regulatory reform plan issued by the Obama presidency was aimed at rebuilding trust in financial markets, particularly banks, and stipulated the need to clarify fair value, impairment and loan-loss provision accounting requirements by the end of 2009 (US Treasury, 2009).
} 
... new ways of working together towards the goal of comparable financial reporting around the world ... and it could include other [non-IASB] standard-setters from major capital markets (Seidman, 2012, speech to AICPA).

SEC and FASB expanded their scope of concern over pursuing convergence solely with IASB (SEC, 2014), with SEC leadership stating " $[t]$ he key ... is not necessarily to converge ... but rather to expand timely access to information and provide for understanding differences" (Stein, 2015). ${ }^{34}$ Thus, IASB-convergence caution was firmly established in the US, despite continuing discord with transnational/international bodies supporting convergence, ${ }^{35}$ and the IASB chair expressing frustration at "turning back the clock" (MacIntosh, 2014) ${ }^{36}$ Although communicating to "keep each other's views ... in mind", the interaction between IASB and FASB was described as "often with an adversarial tone" (Katz, 2015). Most recently, SEC's chief accountant, alerted that "there is virtually no support to have the SEC mandate IFRS" (James Schnurr, quoted in Katz, 2015). Potentially therefore, IASB and FASB may be independently more receptive to ideological perspectives from other standard-setters. However, research in the Japanese context suggests otherwise where there is evidence of the US exerting pressure on Japan to adopt accounting practices which supports neoliberal capitalism (Gallhofer et al., 2012).

\section{Strengthening coalitions, seeking new targets and evolving mobilisation tactics}

As the IASB-FASB alliance disentangled, another interesting turn in the empirical story surfaced which fuelled PWYP's campaign success. First, PWYP continued strengthening its coalition base (Table 1, Panel A), from 18 in 2006 when the struggle over IFRS8 began, to 33 in 2013, by which time PWYP had successfully led diffusion of CbCR regulation in several significant jurisdictions. ${ }^{37}$ Over this time, PWYP had developed away from minimalistic coalition management to become a strong centre of coordination, delegating clear responsibility to national coalitions and creating a culture of sharing skills and knowledge across coalitions (Cox, 2011; Batchelor and Hearn, 2013; Litvinoff, 2015).

\footnotetext{
${ }^{34}$ In their draft work-plan, SEC have restated their global convergence commitment of accounting standards and capital market globalisation with no mention of IASB, elaborating: "The SEC will continue to work closely with its regulatory counterparts abroad, as well as with relevant international organizations, to promote high-quality securities regulation worldwide and convergence where appropriate" (SEC, 2014, p23).

${ }^{35}$ Bodies included: EU (Barnier, 2010), G20 (G20 Leaders, 2013), the Financial Stability Board (Deloitte, 2013) and IASB (MacIntosh, 2014). However, it is worth noting that ICAEW has suggested the IASB should end its convergence project with FASB and focus on jurisdictions which have already adopted IFRS (ICAEW, 2012).

${ }^{36}$ However, the IFRS Foundation later divulged that it had "no longer been working jointly with the FASB on [its conceptual framework] project" and was working towards "receive[ing] input from a broad range of accounting standard setters, including FASB, through the Accounting Standards Advisory Forum" (IFRS Foundation, 2015b, p13).

37 The focus of this paper is on PWYP's success developing, diffusion and instituting CbCR in the EU. However, it is pertinent to note that, at the time of writing, regulations in the European Union, Canada, Norway and the USA have been adopted that oblige extractive companies to prepare CbCR (PWYP, 2016; Chatzivgeri, 2017). Australia has passed legislation (PWC, 2013) with similar developments in Canada and other non-EU countries (Murphy, 2012; PWYP, 2015b; Williams, 2015). National coalitions in Africa and beyond are working towards implementation of regional legal frameworks and revisions to relevant mining and petroleum codes (PWYP, 2016).
} 
Second, having been unsuccessful targeting IASB to accept CbCR and propagate diffusion, PWYP changed their focus to campaign to legislative reform by national legislators. Specifically, in 2007, a hearing of the US government's House Financial Services Committee facilitated PWYP inclusivity; a member of PWYP US Coalition gave testimony, advocating that:

New legislation should require disclosure of payments in this discrete but vital segment of the international economy. In doing so, it would constitute a crucial piece of multipronged international effort to curb corruption in the extractive industries and would ultimately make the business environment more favourable to international firms navigating these difficult waters (Oxfam America, Resource Governance, 2007).

Subsequently, s1504 of the Dodd-Frank Act was signed into US legislation in 2010, and delegated SEC to write rules (which were published in 2012) detailing how US listed extractive companies should disclose payments made to national governments for the right to extract natural resources (Williams, 2015). At this time, the US was hailed as global leader in the cause for transparency and fighting corruption in the extractive industries (Ross, 2015). This inspired PWYP advocates to call for Europe to adopt similar legislation (Litvinoff, 2015) with the European Commission relating $\mathrm{CbCR}$ to:

... international developments in this field, in particular the inclusion of a requirement to report payment to governments in the Dodd-Frank Act in the United States (European Commission, 2013, para. 1, 5).

However, continuing legal challenge to SEC from the American Petroleum Institute relating to perceived implementation costs and disclosing commercially sensitive information, together with recent changes to the US political landscape, have delayed implementation of s1504 (Ross, 2015). ${ }^{38,39}$ Notwithstanding this troubled US context, PWYP successfully recruited allies within European political opportunity structures. ${ }^{40}$ PWYP claims and evidences themselves as a powerful international civil society movement which has led to the European Union's 2013 Accounting and Transparency)Directive requiring extractive companies to report their payments to governments (Litvinoff, 2015, p8), stating:

As a first mover, PWYP opened a high-level dialogue with EU political leaders and officials in influential member states, with European Commissioners and with MEPs well before the first legislative proposals emerged. It combined "long term advocacy and persistent messaging ... [with] responding to moments of opportunity".

Third, PWYP evolved away from the loosely orchestrated ED8 comment letter campaign, to lever their agency by more sophisticated means. PWYP recruited high profile champions to advance their contestation. For example: Arlene McCarthy MEP; George Soros, founder of Open Society

\footnotetext{
${ }^{38}$ The American Petroleum Institute (2016) is the trade association that represents America's oil and gas industry.

${ }^{39}$ The US situation deteriorated still further following the inauguration as President Trump who has repealed a new rule imposed by SEC to implement section s1504 (Chatzivgeri, 2017).

${ }^{40}$ It is out with the scope of this paper to investigate PWYP's engagement with non-IASB political opportunity structure. However, it is worth noting that in 2010, PWYP political allies tabled motions in the UK Parliament in 2010 in efforts to mitigate the resource-curse by mandating CbCR (PWYP. 2015)
} 
Foundation; Bono, civil society activist and lead singer of U2; Bill Gates founder the Bill \& Melinda Gates Foundation; and Kofi Annan, the then UN Secretary General all lent their visible support to PWYP's campaign for CbCR. Such support was undoubtedly helped by the drama and opportunity of the GFC, which increased awareness of corporate activities' impact on inequality and corruption (Cox, 2011, Litvinoff, 2015). PWYP also pursued productive alliances with other ideologically similar organisations, as interestingly advised by IASB in 2006 (IASB, 2006a, BC50). For example, in Australia, the Tax Justice Network and PWYP campaigned for tax transparency through CbCR (Tax Justice Network and PWYP, 2015). Similarly, Eurodad and Transparency International worked closely with PWYP, emphasising the importance of "civil society organisation[s] join[ing] efforts to ensure ... key provisions of the European Commission's [CbCR] proposals be guaranteed" (Eurodad, 2012; Transparency International, 2015). Through these alliances, PWYP joined forces with Fiends of the Earth, One, and Tearfund to attract publicity through the launch of an emotive transparency advert published in the Financial Times telling the European Union that 'The World is Watching' (JustPolicy, 2012).

Thus, aided by IASB resisting PWYP's campaign and the adverse publicity that ensued over the IFRS8 affair, followed by the exogenous financial crisis shock, PWYP was able to strengthening coalitions, shift the target of its agency and evolve mobilisation tactics, leading to diffusion and institutionalisation of a form of emancipatory accounting in $\mathrm{CbCR}$, which:

... when fully enacted, ... will be the first accounting standard formulated and developed by civil society rather than the traditional accounting standard-setters. It represents the first time activists have demanded and secured an accounting standard that the establishment was not keen on in the social media age (Sikka, 2013).

The shift the balance of power away from the IASB as the controlling influence over accounting standard-setting for TNCs has been motivated through social movement action. The resulting $\mathrm{CbCR}$ captures accounting practice that informs citizens of matters that will empower them to protect their civil rights. Indeed, PWYP now claims IASB is suffering from a crisis of legitimacy, saying:

The IASB has essentially been sidestepped by governments and regulators which are more accountable and responsive to the needs of a wide range of users of financial information (International Director of PWYP, 2014).

\section{Concluding comments}

This paper has contributed to understanding how PWYP's social movement was successful in diffusing and institutionalising mandatory $\mathrm{CbCR}$, an emancipatory form of accounting, in several significant jurisdictions across the globe. Globalisation and embedded conflicts therein have been discussed to highlight emancipatory potential and opportunity, drawing on the critiques of Gallhofer and Haslam (2003, 2006, 2007 and 2017). Locating the analysis within the struggle over IFRS8 as a focus for critical exploration, insight into mobilisation of emancipatory accounting change for TNCs was sought. The timeframe explored started in 2006 when IASB adopted IFRS 8 after excluding 79 PWYP comment letters responses from their pre-adoption analysis. Including the shocking GFC, the timeframe explored continued to 2013 when IASB published IFRS8's post- 
implementation review (IFRS Foundations, 2013a) and the European Parliament incorporated mandatory $\mathrm{CbCR}$ within the EU Accounting and Transparency Directives (European Commission, 2013). Over this timeframe, two emancipatory moments are illuminated. First, evidence of the development of a more democratic process for TNC accounting standard-setting through an elaboration of IASB's due process, to include a post-implementation review, together with the disentanglement of IASB-FASB's powerful hegemonic alliance. Second, evidence of international accounting's processual development towards diffusing instituting, for the first time, an accounting practice developed by civil society to account for some social consequences of international business, in addition to the economic consequences for global capital market participants. This paper argues that the window of opportunity in IASB's due process over IFRS 8 initiated these incremental emancipatory changes, subsequently facilitated by the drama and ironic opportunity of the GFC, away from a narrow and quite singular focus on providing information "by capitalists for capitalists" (Catchpowle and Smyth, 2016, p232), to include information for advancing the well-being of citizens.

Although ultimately unsuccessful in influencing IASB, the struggle over IFRS8 has illuminated key factors that worked to enable or constrain PWYP's campaign. First, the timing of IASB's public consultation over ED8, prior to adopting IFRS8, provided PWYP with a window of opportunity to engage in IASB's due process. Due process is the mainstream standard-setting mechanism of the IASB, with potential to "increase and sustain governance and financial transparency" and a potential avenue for influencing emancipatory accounting change (Gallhofer and Haslam, 2007, p.659). IASB's introduction of a post-implementation review arguably evidences an emancipatory moment in the direction of more democratic governance over IASB's activities $^{41}$ by: proactively arranging outreach events; considering the findings from non-US academic research; and seeking open and transparent consultation through its Request for Information. However, IASB did not want to threaten its FASB convergence goals and used its institutional power to exclude PWYP coalition letters from consideration prior to adopting IFRS8, and excluded PWYP concerns from the post-implementation review. This meant that PWYP was unsuccessful in trying to mobilise CbCR through IASB's due process.

Throughout the timeframe explored in this paper, PWYP's central contestation against the resource curse did not change. Neither did the framing of their arguments to mobilise $\mathrm{CbCR}$ for the good of business and investors to assess country-specific risks and civil society to hold national governments to account. However, IASB's resistance to PWYP's campaign meant PWYP had to change the focus of their agency and set out to persuade national legislators to reform transparency legislation. Fortuitously, while the IASB-FASB alliance was disentangling in the aftermath of the GFC, the increased awareness the GFC created of corporate activities' impact on inequality and corruption (Cox, 2011, Litvinoff, 2015) correlated with PWYP: (i) strengthening its coalition base, coordination and sharing skills and knowledge; (ii) shifting the target of its agency away from IASB to propagate $\mathrm{CbCR}$ through national legislators; and (iii) evolving tactics away from a lightly managed comment letter campaign to: leverage support from ideologically similar

\footnotetext{
${ }^{41}$ Indeed, the IFRS Foundation have recently launched a new initiative called 'Evidence-Supported Standard-Setting' together with the IFRS Research Centre (IFRS Foundation, 2015c), actively seeking to engage with academic research to inform the IFRS work plan. Thus, academic research can potentially directly influence accounting practice, rather than waiting for "academic work to percolate out into civil society" (Spence, 2009, p.222, recognising the work of Cooper et al., 2005).
} 
organisations; recruit high profile champions; and proactively seek media coverage for their campaign. As a result, significant advances towards mandating CbCR in several nations across the world are now evident. Particularly, the EU Accounting and Transparency Directives mandate $\mathrm{CbCR}$ for large and listed extractive companies, effective from $1^{\text {st }}$ January $2016^{42}$, and national legislation in Canada, Norway and USA, ${ }^{43}$ have been adopted that obligate extractive companies to prepare CbCR (PWYP, 2016; Chatzivgeri, 2017).

Notwithstanding the situation in the US, there are two broad challenges facing PWYP and its allies as they continue to campaign for full CbCR in pursuit of revenue and tax transparency across the globe. Specifically, CbCR mandated in several jurisdictions falls short of that advocated by PWYP and its allies (see Table 2) necessitating continued campaigning for full CbCR. Given IASB's strategy to exclude $\mathrm{CbCR}$ from its pronouncements, civil society organisations will need to mobilise institutional change through regional and national political opportunity structures. Also, although [a form of] $\mathrm{CbCR}$ has been advanced in several jurisdictions, the form of the report has not been mandated nor is it required to be audited (Chatzivgeri et al., 2017). This gives reporting entities considerable scope to determine the form and quality of $\mathrm{CbCR}$ disclosures. Further research is therefore called for to provide empirical evidence that can illuminate these challenges. On a positive note, the European Commission has launched a public consultation in respect of $\mathrm{CbCR}$ for all listed and large non-listed extractive companies in the EU, emphasising:

The fight against corporate tax avoidance [being] a top priority of this Commission.... The Commission's work follows through on the commitments made by G20 leaders, who have pledged to ensure that tax authorities freely exchange information about large multinationals, including their CBCR (European Commission, 2015).

In conclusion, PWYP has emerged from the initial struggle over IFRS8 as a new influential constituency in global accounting standard-setting. This shift in the balance of power away from IASB does not constitute a radical revolution, but reveals how narrow institutional reform efforts through struggle give rise to "incremental trajectories of change" (Shneiberg and Lounsbury, 2008, p653). It may be argued that PWYP facilitated this shift by pursuing alliances to encapsulate "... a diversity of particular political demands" (Spence, 2009, p216) all concerned with securing the civil rights of those affected by TNC activities, particularly in resource-rich countries (Gallhofer et al., 2015). Such interventions align with Gallhofer and Haslam's (2006) thesis of continuum thinking that emancipatory moments can be achieved through struggle. This subtle shift in ideology potentially steers accounting practice to develop in a way that is 'respectful of difference' in pursuit of 'betterment' to society; in contrast to documented evidence of pursuing 'global sameness' for effective capital market stakeholders (Gallhofer and Haslam, 2003; Gallhofer et al., 2015).

One final observation on the power of publicity is here made. Noise in the financial press at the time IFRS 8 was adopted by IASB in 2006 reflected concerns raised by PWYP in pursuit of their

\footnotetext{
${ }^{42} \mathrm{CbCR}$ requirements were implemented one year early in the UK (Chatzivgeri et al.,, 2017)

${ }^{43}$ In 2016, SEC rewrote implementation rules in respect of s1504 of the Dodd-Frank Act after a successful legal challenge from US extractive companies to SEC rules of 2012. However, at the time of writing (2017), the Trump Presidency had given approval to repeal this rule, although the law (s1504) remains intact (Chatzivgeri, et al., 2017).
} 
campaign (Crawford et al., 2010). ${ }^{44}$ Through transnational social movement protest by PWYP against the resource-curse, and related media attention highlighting capital market failure, global capitalism's impact on inequality ${ }^{45}$ was made more visible (Neveling, 2007; Sukhraj, 2007; Sikka, 2009; Roulet, 2014), specifically in the context of the extractive industries. The power of the media is a critical facilitator in publicising institutional conflicts (Roulet, 2014) and arguably helped PWYP's campaign against the resource-curse. IASB's decision to exclude PWYP's concerns from its policy making process was publicised in the financial media, giving visibility to the conflicted institution of international accounting setting, where concerns about the resource-curse were seemingly ignored. ${ }^{46}$ This is illustrative of Bentham's utilitarian argument of publicity being the arbitrator of democracy (see Gallhofer and Haslam, 2003), echoed in the contemporary observation that "things start to move when people at the margins get hold of the microphone" (Fidgen, 2015). As accounting moves in the direction of reflecting a more inclusive social truth towards achieving social happiness, more might come to reflect on the words of a modern-day observer of society - "clap your hands if you think that happiness is the truth" (Williams, 2013).

\section{Acknowledgements}

The author would like to recognise the professional body research grants, received from The Institute of Chartered Accountants in England and Wales and The Institute of Chartered Accountants of Scotland. These grants underpinned original research efforts towards understanding the standard-setting process and impact of IFRS8. The author would also like to thank feedback and support received from participants of the Abu Dhabi 2013 CSAF International Conference, and particularly Professor Jim Haslam for the special session on 'Reflecting on Emancipatory Accounting: Developing the Emancipatory in Accounting', and related feedback and encouragement. Finally, the author would like to thank James Royston, PWYP Secretariat for providing information presented in Table 1 of this paper.

\footnotetext{
${ }^{44}$ Leading to the European Parliament, in their reserved endorsement of IFRS8, stating that "convergence of accounting rules is not a one-sided process where one party [IASB] simply copies the financial reporting standards of the other party [FASB]" and that geographical information should be disclosed "where relevant [using] country-bycountry" disclosure (European Parliament, 2007; Crawford et al., 2010).

${ }^{45}$ Most recently exposed through the Panama Papers leak and the continuing austerity measures in the aftermath of the financial crisis.

${ }^{46}$ Further institutional conflict arising from the activity of TNC were made visible by the media publicising significant inequalities arising from the financial crisis where the level of global poverty-inequality continues to rise and state imposed austerity measures persist (Roulet, 2014; BBC, 2014). More recently revelations over unethical tax practices exposed by the leaked Panama papers, and alleged corruption payments from western extractive corporates to an intermediary in Monaco, highlight still further neoliberalism's focus on generating profit for investors over meeting the needs of other members of society (Huffington Post and Fairfax Media (2016).
} 


\section{References}

Abrahamson, E. (2011). The Iron Cage: Ugly, Uncool and Unfashionable. Organisation Studies, $32(5), 615-629$.

Abrahamson, E. and Rosenkopf, L. (1997). Social network effects on the extent of innovation diffusion: A computer simulation. Organisation Science, 8 (3), 289-309.

Action against impunity for human rights (ACIHD), (2006), Comment Letter (CL) 43 to Exposure Draft 8 Operating Segments - Need for reporting on country-by-country basis. Available at: http://www.ifrs.org/Current-Projects/IASB-Projects/Segment-Reporting/Exposure-Draft-andComment-Letters/Comment-Letters/Documents/16_227_CL43.pdf, accessed July 2015.

Allianz Aktiengesellschaft (2006). Comment Letter (CL) 164 to Exposure Draft 8 'Operating Segments'. Available at: http://www.ifrs.org/Current-Projects/IASB-Projects/SegmentReporting/Exposure-Draft-and-Comment-Letters/Comment-

Letters/Documents/16 227 Exposure Draft 8 CL164.pdf, accessed August 2015.

American Petroleum Institute (2016). About API. Available at: http://www.api.org/about, accessed May 2016.

Anglo Platinum (2006). Comment Letter (CL) 63 to Exposure Draft 8 Operating Segments. Available at: http://www.ifrs.org/Current-Projects/IASB-Projects/Segment-Reporting/ExposureDraft-and-Comment-Letters/Comment-Letters/Documents/16_227_CL63.pdf, accessed August 2015.

Arnold, P. (2009). Institutional perspectives on the internationalisation of accounting. In C. Chapman, D. Cooper \& P. Miller (Eds.), Accounting organisations and institutions: essays in honour of Anthony Hopwood (pp. 48-65). Oxford: Oxford University Press.

Barnier, M. (2010). Building a new financial framework together. SPEECH/10/231, 11 May 2010. European Institute: Washington.

Bahmueller, C. F. (1981). The National Charity Company: Jeremy Bentham's Silent Revolution. University of California Press: Berkeley, Los Angeles and London.

Batchelor, S. and Hearn, S. (2013). Coalitions for Transparency in Extractive Industries: A study of the coalition model of the Publish What You Pay campaign. Overseas Development Institute: London.

BBC (2014). The end of capitalism: Reforming capitalism. BBC Radio 4 - Thinking Allowed, presented by Laurie Taylor. London: British Broadcasting Corporation.

Bengtsson, E. (2011). Repoliticalisation of accounting standard-setting - the IASB, the EU and the global accounting crisis. Critical Perspectives on Accounting, 22 (8), 567-580. 
Bjornanak, T. (1997). Diffusion and accounting: the case of ABC in Norway. Management Accounting Research, 8, 3-17.

Botzem, S (2014). Transnational standard-setting in accounting: Organizing expertise-based selfregulation in times of crises. Accounting, Auditing and Accountability Journal, 27 (6), 933- 955.

Brancheau, J. C., \& Wetherbe, J. C. (1990). The adoption of spreadsheet software: testing innovation diffusion theory in the context of end-user computing. Information Systems Research, 1(2), 115-143.

Brown, J. (2017). Democratizing accounting: Reflections on the politics of "old" and "new" pluralisms. Critical Perspectives on Accounting, 34, 20-46.

Burlaud, A. \& Colasse, B. (2011). International Accounting Standardisation: Is politics back? Accounting in Europe, 8(1), 23-47.

Catchpowle, L. and Smyth, S. (2016). Accounting and Social movements: An exploration of critical accounting praxis. Accounting Forum, 40, 220-234.

Cox, B. (2011). Campaigning for International Justice: Learning Lessons (1991-2011) - Where Next? (2011-2015). Bond: London.

Civil Rights Movement (2016). Civil Liberties or Civil Rights? Available at: http://www.civilrightsmovement.co.uk/civil-liberties-civil-rights.html, accessed June 2016.

Chatzivgeri, E., Chew, L., Crawford, L., Gordon, M. and Haslam, J. (2017). Reports on payments to governments: a report on early developments and experiences. Available at, accessed http://www.publishwhatyoupay.org/raising-global-standards-of-transparency-in-the-extractivessector/, June 2017.

Chiapello, E. (2017). Critical accounting research and neoliberalism. Critical Perspective on Accounting, 45, 47-64.

Chiapello, E. \& Medjad, K. (2009). An unprecedented privatisation of mandatory standard-setting: The case of European accounting policy. Critical Perspectives on Accounting 25 (4), 448-468.

Christian Aid (2006). Comment Letter (CL) 146 to Exposure Draft 8 Operating Segments - Need for reporting on country-by-country basis. Available at: http://www.ifrs.org/CurrentProjects/IASB-Projects/Segment-Reporting/Exposure-Draft-and-Comment-Letters/CommentLetters/Documents/16 227 Exposure Draft 8 CL146.pdf accessed July 2015.

Cooper, C. and Coulson, A. (2014). Accounting activism and Bourdieu's 'collective intellectual' - Reflections on the ICL case. Critical Perspectives on Accounting, 25, 237-254. 
Cooper, C., Neu, D. \& Lehman, G. (2003). Globalisation and its discontents: a concern about growth and globalisation. Accounting Forum, 27 (4), 359-364.

Cooper, C., Taylor, P., Smith, N. \& Catchpowle, L. A (2005). Discussion of the political potential of Social Accounting. Critical Perspectives on Accounting, 16 (7), 951-974.

Crawford, L., Helliar, C.V. \& Power, D.M. (2010). Politics or Accounting Principles: Why was IFRS8 so controversial? London: ICAEW.

Crawford, L., Extance, H., Helliar, C.V. \& Power, D.M. (2012). Operating segments: The usefulness of IFRS 8. Edinburgh: ICAS.

Crawford, L., Ferguson, R.J., Helliar, C.V. \& Power, D.M. (2014). Control over accounting standards within the European Union: The political controversy surrounding the adoption of IFRS 8. Critical Perspectives on Accounting, 25, 304-308.

Dallyn, D. (2016). An examination of the political salience of corporate tax avoidance: A case study of the Tax Justice Network. Accounting Forum, available online https://doi.org/10.1016/j.accfor.2016.12.002

Banjou, P. and Walton, P. (2012). The Legitimacy of the IASB. Accounting in Europe, 9 (1), 1 15 .

della Porta, D. and Kriesi, H. (2009). Social Movements in a Globalising World: an Introduction. In D. della Porta, H. Kriesi and D. Dieter Rucht (Eds), Social Movements in a Globalised World. Hampshire, UK and New York, USA: Palgrave Macmillan.

Denedo, M., Thomson, I. and Akira Yonekura, A. (2017) "International Advocacy NGOs, Counter Accounting, Accountability and Engagement", Accounting, Auditing \& Accountability Journal, in press - https://doi.org/10.1108/AAAJ-03-2016-2468

Deloitte (2009). Deloitte podcast - move toward IFRSs in the US. Available athttps://www.iasplus.com/en/news/2009/June/news5011, accessed June 2017.

Deloitte (2013). FSB takes stock after five years: Convergence of accounting standards still 'amber'. Available at: https://www.iasplus.com/en-gb/news/2013/09/fsb-g20, accessed June 2017.

Dodd-Frank Act (2010). Dodd-Frank Wall Street Reform and Consumer Protection Act, Federal Law.

Dryzek, J. S. (2011). Global Democratisation: Soup, Society, or System? Ethics and International Affairs, 25 (2), 211-234.

Durocher, S., Fortin, A. \& Cote, L. (2007). Users' participation in the accounting standard-setting process: A theory-building study. Accounting, Organizations and Society, 32 (1-2), 29-59.

EITI (2015a). History of EITI. Available at: https://eiti.org/eiti/history, accessed August 2015. EITI (2015b). EITI countries. Available at: https://eiti.org/countries, accessed August 2015. 
Eurodad (2012). Lobby pack: EU Directives on Transparency by Multinationals.

Eurodad (2016). European Network on Debt and Development. Available at: http://www.eurodad.org/sites/about, accessed June 2016.

European Commission (2007). Endorsement of IFRS 8 Operating Segments: Analysis of potential effects. Brussels: European Parliament. Available at: http://eur-lex.europa.eu/legalcontent/EN/TXT/PDF/?uri=CELEX:02002R1606-20080410\&from=EN, accessed August, 2015.

European Commission (2010). Report from the Commission to the European Parliament and the Council - Report on the funding of the International Financial Reporting Standards Foundation. Brussels: European Commission

European Commission (2013). Memo July 2013: Commissioner Barnier welcomes the European Parliament vote on the Accounting and Transparency Directives (including country by country reporting). Available at: http://europa.eu/rapid/press-release_MEMO-13-546 en.htm, accessed May 2016.

European Commission (2015). Press release - Commission launches public consultation on corporate tax transparency, Brussels, 17 June 2015. Available at: http://europa.eu/rapid/pressrelease_IP-15-5156_en.htm?locale=en, accessed August 2015.

European Parliament (2002). Regulation (EC) No 1606/2002 of the European Parliament and of the Council of 19th July 2002 on the application of international accounting standards. Brussels: Official Journal of the European Communities

European Parliament (2007). Resolution of 14 November 2007 on the draft Commission regulation amending Regulation (EC) No 1725/2003 adopting certain international accounting standards in accordance with Regulation (EC) No 1606/2002 of the European Parliament and of the Council as regards International Financial Reporting Standard (IFRS) 8, concerning disclosure of operating segments, http://www.europarl.europa.eu/sides/getDoc.do?pubRef=-//EP//TEXT+TA+P6-TA2007-0526+0+DOC+XML+V0//EN\&language=EN, accessed 3 November 2009.

European Parliament (2012). Charter of Fundamental Rights of the European Union. Official Journal of the European Union, 26.10.2012.

European Securities and Markets Authority (ESMA) (2011). Review of European enforcers on the implementation of IFRS 8 - Operating Segments, 9 November 2011, ESMA/2011/372. Paris.

Everett, J. (2003), Globalisation and its new spaces for (alternative) accounting research. Accounting Forum, 27 (4), 400-424.

FASB (1997). Statement of Financial Accounting (1997) Standards No. 131 Disclosures about Segments of an Enterprise and Related Information. Norwalk, CT: FASB.

FAF (2010). Financial Accounting Foundation Appoints Leslie F. Seidman Chairman of the Financial Accounting Standards Board, 23 December 2010. Available at: http://www.accountingfoundation.org/cs/ContentServer?c=FAFContent C\&pagename=Foundati on/FAFContent_C/FAFNewsPage\&cid=1176158080171, accessed June 2017. 
FASB (1997). Standard no 131 - Disclosures about segments of an enterprise and related information. US: FASB.

Ferguson, J., Collison, D., Power, D. and Stevenson, L. (2006). Accounting textbooks: Exploring the production of a cultural and political artefact. Accounting Education, 15 (3), 243-260.

Fidgen, J. (2015). Analysis - How gay became OK, BBC Radio 4, and 22nd June 2015. Available at: http://www.bbc.co.uk/programmes/b05zh141, accessed 1st August 2015.

Finér, L. and Ylönen, M. (2016). Tax-driven wealth chains: A multiple case study of tax avoidance in the Finnish mining sector. Critical Perspectives on Accounting. In press https://doi.org/10.1016/j.cpa.2017.01.002

Fogarty, T.J., Hussein, M.E.A. \& Ketz, J.E. (1994). Political Aspects of Financial Accounting Standard-setting in the USA. Accounting, Auditing \& Accountability Journal, 7 (4), 24-46.

FRRP (2010). FRRP highlights the challenge of implementing new segmental reporting requirements, FRRP PN 124. Available at: http://www.frc.org.uk/frrp/press/pub2203.html, accessed 18 January 2010.

G20 Leaders (2013). Russia G20: G20 Leaders Declaration. Available at: http://www.g20.utoronto.ca/2013/2013-0906-declaration.html, accessed June 2017.

Gallhofer, S. \& Haslam, J. (2003). Accounting and Emancipation: Some Critical Interventions. New York: Routledge.

Gallhofer, S. \& Haslam, J. (2006). The accounting-globalisation interrelation: An overview with some reflections on the neglected dimension of emancipatory potentiality. Critical Perspectives on Accounting, 17 (7), 903-934.

Gallhofer, S. \& Haslam, J. (2007). Exploring social, political and economic dimensions of accounting in the global context: the International Accounting Standards Board and accounting disaggregation. Socio-economic Review, 5 (4), 633-664.

Gallhofer, S. \& Haslam, J. (2011). Emancipation, the spiritual and accounting. Critical Perspectives on Accounting, 22 (5), 500-509.

Gallhofer, S., Haslam, J. \& Yonekura, A. (2012). Accounting disclosure, corporate governance and the battle for markets: The case of trade negotiations between Japan and the US. Critical Perspectives on Accounting, 23 (4-5), 312-331.

Gallhofer, S. \& Haslam, J. (2017). Some reflections on the construct of emancipatory accounting: Shifting meaning and possibilities of a new pragmatism. Critical Perspectives on Accounting, in press - https://doi.org/10.1016/j.cpa.2017.01.004

Gallhofer, S., Haslam, J. \& Yonekura, A. (2015). Accounting as differentiated universal for emancipatory praxis: Accounting delineation and mobilisation for emancipation(s). Accounting, Auditing and Accountability Journal, 28(5), 846 - 874. 
Graham, C. \& Neu, D. (2003). Accounting for Globalisation. Accounting Forum, 27 (4), 449471.

Herz, R. H. (2009). History Doesn't Repeat Itself, People Repeat History - Front-Line Thoughts and Observations on Creating a Sounder Financial System, FASB Chairman Robert H. Herz Presentation to the National Press Club in Washington, DC on June 26, 2009. FASB: Norwalk, CT.

Hopper, T., Lassou, P. and Soobaroyen, T. (2017). Globalisation, accounting and developing countries. Critical Perspectives on Accounting, 43, 125-148.

Huffington Post and Fairfax Media (2016). World's biggest bribe scandal: The company that bribed the world. Available at: http://www.theage.com.au/interactive/2016/the-bribe-factory/, accessed May 2016.

Humphrey, C., Loft, A \& Woods, M. (2009). The global audit profession and the international financial architecture: Understanding the regulatory relationship at a time of financial crisis. Accounting, Organisations and Society, 34, 810-882.

IASB (1997). International Accounting Standard 14(revised)-Segment Reporting. London: IASB.

IASB (2006a) International Financial Reporting Standard 8 'Operating Segments. London: IASB.

IASB (2006b). Comment letters on Exposure Draft 8. Available at: http://www.ifrs.org/CurrentProjects/IASB-Projects/Segment-Reporting/Exposure-Draft-and-Comment-Letters/CommentLetters/Pages/Comment.aspx, accessed 16 August 2010.

IASB (2006c). Exposure Draft ED 8 'Operating Segments': comments to be received by 19 May 2006. London: IASB.

IASB (2006d). Observer Notes: Segment Reporting: Analysis of comment letters to ED 8 (Agenda Paper5).http://www.ifrs.org/NR/rdonlyres/5077510D-EB73-48E2-9DE0-

7AEE9752BAAD/0/ObNotes_OpSeg0607ob05.pdf, re-accessed March 2012

IASB Update (2011a). Available at: http://www.ifrs.org/Updates/IASBUpdates/2011/Documents/AASBupdateSept2011.pdf, accessed July 2015.

IASB Update (2011b). Available at: http://media.iasb.org/IASBupdateNovember2011.html, accessed July 2015.

IASB (2012). IASB Agenda ref 8: Post-implementation review of IFRS 8: Update on progress made to February 2012.

IASB (2015). IASB Update, May 2015. Available at: http://media.ifrs.org/2015/IASB/May/IASBUpdate-May-2015.html, accessed May 2016.

ICAEW (2012). The future of IFRS: Information for future markets. ICAEW: London. 
IFAC (2015a). Independent Standard-setting Boards. Available at: https://www.ifac.org/, accessed August 2015.

IFAC (2015b). Available at: https://www.ifac.org/about-ifac/membership/compliance-program, accessed August 2015.

IASB/FASB (2006). Memorandum of Understanding - A Roadmap for convergence between IFRSs and US GAAP, 2006-2008. Available at: $\mathrm{http} / / /$ www.fasb.org/cs/ContentServer?c=Document_C\&pagename=FASB $\% 2$ FDocument_C $\% 2$ FDocumentPage\&cid=1176156245558, accessed July 2015.

IFRS Foundation (2006). Work plan for IFRSs - Segmental reporting. Available at http://www.ifrs.org/Current-Projects/IASB-Projects/Segment-Reporting/Pages/SegmentReporting.aspx, accessed July, 2015.

IFRS Foundation (2010a). Staff Paper, Agenda Ref 7A - Extractive Activities, Comment Letter Summary. Available

at: http://www.ifrs.org/Meetings/Documents/IASBOct10/Extractives1010b07Aobs.pdf, accessed May 2016.

IFRS Foundation (2010b). The conceptual Framework for Financial Reporting 2010. London: IASB.

IFRS Foundation (2011). Post implementation reviews: plan for developing the framework for conducting post-implementation reviews. IASB Board meeting February 2011, Available at: http://www.ifrs.org/NR/rdonlyres/3E1502E4-F1E8-4907-838B $\quad$ FFB20C7268ED/0/ postimplementation review 02111st2ndb04obs.pdf, accessed 27th July 2011.

IFRS Foundation (2012a). IFRS Foundation Trustees meeting- Due Process Oversight Committee: Post-implementation reviews, an overview. London: IASB.

IFRS Foundation (2012b). IASB Agenda Ref 8 - Post-implementation review of IFRS 8 - Paper topic Update on progress made to February 2012. Available at: http://www.ifrs.org/Meetings/Documents/IFRS80312b08.pdf, accessed July 2015.

IFRS Foundation, (2012c). Staff Paper, Agenda Ref 10A - Annual Improvements to IFRSs - 20102012 Cycle (ED/2012/1) comment letter analysis Paper topic IFRS 8 Operating Segmentsaggregation of operating segments. Available at: http://www.ifrs.org/Current-Projects/IASBProjects/IFRS-8-operating-segments-aggregation/Documents/101211AP10A\%20-

$\% 20$ CL $\% 20$ analysis\%20-

\%20IFRS\%208\%20Aggregation\%20of\%20operating\%20segments.pdf, accessed July, 2015.

IFRS Foundation (2013a). Report and feedback statement - Post-Implementation Review: IFRS 8 Operating Segments, July 2013. Delaware: IFRS Foundation. 
IFRS Foundation (2013b). IASB Agenda ref 6A: Post-implementation review IFRS 8 Operating Segments - Comment letter analysis and summary of outreach conducted. Available at: http://www.ifrs.org/Meetings/Pages/IASBJanuary2013.aspx, accessed August 2015.

IFRS Foundation (2013c). IASB - Who we are and what we do. London: IASB.

IFRS Foundation (2013d). IASB and IFRS Interpretations Committee: Due Process Handbook, February 2013. Delaware: IFRS Foundation (ISBN: 978-1-907877-81-0)

IFRS Foundation (2015a). Mission Statement. Available at: http://www.ifrs.org/Aboutus/Pages/IFRS-Foundation-and-IASB.aspx, accessed July 2015.

IFRS Foundation (2015b). Snapshot: Conceptual Framework for Financial Reporting (May 2015 Exposure Draft). London: IASB.

IFRS Foundation (2015c). Evidence supported standard-setting. Available at: http://www.ifrs.org/IFRS-Research/Evidence-supported-standard-setting/Pages/Evidencesupported-standard-setting.aspx, accessed July 2015.

IMF (2011). Standards and Codes. Available at: http://www.imf.org/external/standards/index.htm, accessed July 2015.

IMF (2014). Working paper 14/5 Resource Blessing, Revenue Curse? Domestic Revenue Effort in Resource-Rich Countries Ernesto Crivelli and Sanjeev Gupta. Available at: https://www.imf.org/external/pubs/ft/wp/2014/wp1405.pdf, accessed August 2015.

IMF (2015). How IMF promotes global economic stability. Available at: http://www.imf.org/external/np/exr/facts/globstab.htm, accessed July, 2015.

Islam, M.A., Dissanajake, T. and Dellaportas, S. (2016). Anti-bribery disclosures: A response to network governance. Accounting Forum, in press - https://doi.org/10.1016/j.accfor.2016.03.002.

Jacobs, K. (2011). Enlightenment and emancipation: Reflections for critical accounting research. Critical Perspectives on Accounting, 22 (5), 510-515.

JustPolicy (2012). JustPolicy Blog - The world is watching. Available at: https://justpolicy.co.uk/2012/11/13/the-world-is-watching/, accessed July 2017.

Katz, D. M. (2015). SEC's Chief Accountant Signals and End to Convergence Efforts. CFO. Available at: http://ww2.cfo.com/gaap-ifrs/2015/05/secs-chief-accountant-signals-endconvergence-efforts/, accessed May 2016.

Kreisi, H.; Koopmans, R; Duyvendak, J.W. and Guigni, M.G. (1995). The Politics of New Social Movements in Western Europe: A comparative Analysis. Minneapolis, MN: University of Minnnesota Press.

Larson, R.K. (2007). Constituent Participation and the IASB's International Financial Reporting Interpretations Committee. Accounting in Europe, 4 (2), 207-254. 
Larson, R.K. \&Herz, P.J. (2013). A multi-issue/multi-period analysis of the geographic diversity of IASB comment letter participation. Accounting in Europe, 10 (1), 99-151.

Larson, R.K. \& Kenny, S.Y. (2011). The financing of the IASB: an analysis of donor diversity. Journal of International Accounting Auditing and Taxation, 20 (1), 1-19.

Lehman, G. (2005). A critical perspective on the harmonisation of accounting in a globalised world. Critical Perspectives on Accounting, 16 (7), 975-992.

Lehman, G. (2009). Globalisation and the internationalisation of accounting: New technologies, instrumentalism and harmonisation. Critical Perspectives on Accounting, 20 (4), 445-447.

Lehman. G. (2017). The language of environmental and social accounting research: The expression of beauty and truth. Critical Perspective on Accounting, 44, 30-41.

Lister, R (1998). Citizenship and difference: Towards a differentiated universalism. European Journal of Social Theory, 1, 71-90.

Litvinoff, M. (2015). Publish What You Pay's EU mandatory disclosure campaign. London: PWYP.

Loft, A., Humphrey, C. \& Turley, S. (2006) 'In Pursuit of Global Regulation: Changing Governance and Accountability Structures at the International Federation of Accountants (IFAC)', Accounting, Auditing and Accountability Journal, 19 (3), 428-451.

Mackintosh, I. (2014). Speech given at the IFRS Foundation Conference, London, 24 June 2014.

Martinez-Diaz L. (2005). Strategic experts and improvising regulators: explaining the IASC's rise to global influence. Business and Politics, 7 (3), 1-26.

Marks, G and McAdam, D. (2009). On the Relationship of Political Opportunities to the Form of Collective Action: The Case of the European Union. In D. della Porta, H. Kriesi and D. Dieter Rucht (Eds), Social Movements in a Globalised World. Hampshire, UK and New York, USA: Palgrave Macmillan.

Moberg, J. (2012). Without PWYP, No EITI. Available at: https://eiti.org/blog/without-pwyp-noeiti, accessed May 2016

Moffat, P and Haralampieva, V. (2014). Through the looking glass of the Extractive Industries Transparency Initiative (EITI) in sustainable resource development. Available at https://eiti.org/document/through-looking-glass-role-eiti-sustainable-resource-development, accessed May 2016.

Murphy, R. (2007). A standard nobody likes. In P. Sukhraj (2007a), Accountancy Age (p7).

Murphy, R (2012). CBCR: Accounting for globalisation locally. Richard Murphy for the Tax Justice Network. Norfolk: Tax Justice Network. Available at: http://www.taxresearch.org.uk/Documents/CBC2012.pdf, accessed July 2015. 
Neveling, N. (2007). EU delays IFRS 8 ratification in shock move: European Parliament tables resolution forcing European Commission to reappraise divisive IFRS 8. Accountancy Age May. Available at: http://www.accountancyage.com/articles/print/2188561, accessed 17 December 2009.

Nielson, R.P. and Lockwood, C. (2015). Journal of Business Ethics, First Online, March 2016.

Nobes, C. (2014). The development of national and transnational regulation on the scope of consolidation. Accounting, Auditing and Accountability Journal, 27 (6), 995 - 1025.

Norwalk Agreement (2002). Memorandum of Understanding. Available at: http://www.fasb.org/news/memorandum.pdf, accessed July 2015.

Oranje, M and Parham, H. (2009). Publish What We Learned: An assessment of the Publish What You Pay Coalition. Available at: http://www.publishwhatyoupay.org/wpcontent/uploads/2015/06/Publishing-What-We-Learned.pdf, accessed May 2016.

Ostry, J.D; Loungani, P and Furceri, D. (2016). Neoliberalism: Oversold? Finance and Development, 53 (2) 38-41.

Palea, V. (2015). The political economy of fair value reporting and governance of the standardssetting process: Critical issues and pitfalls from a continental European Union perspective.

Critical Perspectives on Accounting, 29, 1-15.

Passy, F. (2009). Supranational Political Opportunities as a Channel of Globalisation of Political Conflicts. The Case of the Rights of Indigenous Peoples. In Social Movements in a Globalised World, Ed by Donatella della Porta, Hanspeter Kriesi and Dieter Tucht. England: Palgrave Macmillan.

Perry, J. \& Nolke, A. (2006). The political economy of international accounting standards. Review of International Political Economy, 13(4), 559-586.

Pieterse, J. N. (1992). Emancipations, Modern and Postmodern. Development and Change, 23(3), 5-41.

PWC (2013). Tax transparency and country-by-country reporting: An ever changing landscape An Update, October 2013. United Kingdom: Pricewaterhousecoopers LLP

PWYP (2005a). Extracting Transparency: The Need for and International Financial Reporting Standard for the Extractive Industries. United Kingdom: Global Witness and Save the Children UK.

PWYP (2005b). Global Witness - International Accounting Standard 14 Segment Reporting 2005 Update Submission to the International Accounting Standards Board. London: Global Witness Ltd. 
PWYP (2006). Comment Letter (CL) 1 to Exposure Draft 8 Operating Segments - Need for reporting on country-by-country basis, Available at http://www.ifrs.org/Current-Projects/IASBProjects/Segment-Reporting/Exposure-Draft-and-Comment-Letters/Comment-Letters/Pages/CL1.aspx, accessed July 2015. This submission is the same as PWYP (2005) document previously submitted to IASB.

PWYP (2014). Crisis of legitimacy for accounting standard-setters, accessed 2014

PWYP (2015a). Frequently asked questions, available at: http://www.publishwhatyoupay.org/about/f-a-qs/, accessed July 2015.

PWYP, (2015b). Why Mandatory disclosure? Available at: http://www.publishwhatyoupay.org/about/advocacy/mandatory-disclosures, accessed March 2015.

PWYP Objectives (2015c). Objectives. Available at: http://www.publishwhatyoupay.org/about/objectives/, accessed July, 2015.

PWYP (2017a). History. http://www.publishwhatyoupay.org/about/history/, Available at: accessed June 2017.

PWYP (2016). Proud past, bright future PWYP activities report 2012-2015. PWYP: London

PWYP (2017b). About. Available at: http://www.publishwhatyoupay.org/about/, accessed June 2017

PWYP (2017c). PWYP Extracting the Truth: PWYP Passport. Available at: http://extractingthetruth.org/extractingthetruth.html, accessed June 2017.

Resource Governance (2010). Campaign for country by country reporting by companies: Action Pack - New International Financial Reporting Standards for extractives. London: Revenue Watch Institute.

Resource Governance (2015). Five Years and Counting: The SEC Must Step Up and Make Natural Resource Payment Disclosure Rule - 3 August 2015. https://resourcegovernance.org/blog/fiveyears-and-counting-sec-must-step-and-make-natural-resource-payment-disclosure-rule, accessed November 2015.

Roberts, R. (1979). Bentham's poor law proposals. The Bentham Newsletter, 3, 28-45.

Rogers, E.M. (1995) Diffusion of Innovations, Fourth edition, The Free Press: New York

Rogers, E.M. (2003). Diffusion of innovations (5th ed.). The Free Press: New York

Roulet, T. (2014). "What Good is Wall Street?" Institutional Contradictions and the Diffusion of the Stigma over the Finance Industry. Journal of Business Ethics, 130, 389-402. 
Ross, A. (2015). Dodd-Frank's bid to clean up extractive industries stymied by oil business. The Guardian.

Sahlin, K. and Wedlin, L. (2008). Circulating Ideas: Imitation, Translation and Editing. In R Greenwood, C.Oliver, K Sahlin and R. Suddaby (Eds), The Sage handbook of organisational institutionalism. London: Sage.

Sawers, A. (2012). Two Blows against Accounting Convergence. CFO Online Publication. Available at: http://ww2.cfo.com/gaap-ifrs/2012/07/two-blows-against-accounting-convergence, accessed 5th November 2011 and July 2015.

SEC (2008). Roadmap for the potential use of financial statements prepared in accordance with international financial reporting standards by U.S. issuers $17 \mathrm{cfr}$ parts 210, 229, 230, 240, 244 and 249 [release nos. 33-8982; 34-58960; file no. S7-27-08] rin 3235-aj93: Washington DC: SEC.

SEC (2009). Mary Schapiro Sworn In as Chairman of SEC, 2009-11. Available at: https://www.sec.gov/news/press/2009/2009-11.htm, accessed June 2017.

SEC (2011). Work Plan for the Consideration of Incorporating International Financial Reporting Standards into the Financial Reporting System for U.S. Issuers Final Staff Report, July 2013.

SEC (2012). Office of the Chief Accountant - United States Securities and Exchange Commission, p1-137. Washington DC: SEC.

SEC (2014). Strategic Plan Fiscal years 2014-2018: Protecting investors, maintaining fair, orderly, and efficient markets, and facilitating capital formation. Washington, DC: SEC

Stein, K. (2015). Accountants and Capital Markets in an Era of Digital Disruption: Remarks to the Institute of Chartered Accountants in England and Wales and British American Business, September, 2015. Available at: https://www.sec.gov/news/speech/remarks-inst-charteredacctnts.html, accessed June 2017.

Seidman, L., (2012). Remarks by Leslie F. Seidman, Chairman of the FASB, to the American Institute of Certified Accountants National Conference on Current SEC and PCAOB Developments, Tuesday 4th December 2012. Washington, D.C.

SEOP (2015). Stanford Encyclopaedia of Philosophy: Jeremy Bentham. Available at: http://plato.stanford.edu/entries/bentham/, accessed May 2016.

Schneiberg and Lounsbury (2008). Social movements and institutional analysis. In R Greenwood, C.Oliver, K Sahlin and R. Suddaby (Eds), The Sage handbook of organisational institutionalism. London: Sage.

Sikka, P. (2016). Accounting and taxation: conjoined twins or separate siblings? Accounting Forum, in press - https://doi.org/10.1016/j.accfor.2016.12.003

Sikka, P. (2013). CBCR is a victory for citizens over companies. Available at: https://theconversation.com/country-by-country-reporting-is-a-victory-for-citizens-overcompanies-14654, accessed July 2015. 
Sikka, P. (2009). Financial crisis and the silence of the auditors. Accounting, Organizations and Society, 34, 868-873

Sikka, P., Filling, S., \& Liew, P. (2009). The audit crunch: reforming auditing. Managerial Auditing Journal, 24 (2), 135-155.

Spence, C. (2009), Social accounting's emancipatory potential: A Gramscian critique. Critical Perspectives on Accounting, 20 (2), 205-227.

Suddaby, R., Cooper, D.J. and Greenwood, R. (2007). Transnational regulation of professional services: Governance dynamics of field level organisational change. Accounting, Organisations and Society, 32, 333-362.

Sukhraj, P. (2007). Segment reporting row hots up. Accountancy Age (May). Available at: http://www.accountancyage.com/accountancy/analysis/2191097/segmentreporting-standard-row, accessed 17 December 2009.

Tax Justice Network (2006). Comment letter in response to Exposure Draft 8. Available at: http://www.ifrs.org/Current-Projects/IASB-Projects/Segment-Reporting/Exposure-Draft-and-

Comment-Letters/Comment-Letters/Pages/CL-21.aspx, accessed May 2016

Tax Justice Network (2015). The scale of Base Erosion and Profit Shifting. Available at: http://www.taxjustice.net/scalebeps/, accessed June 2015.

Tax Justice Network (2017). Our goals and methods - About us. https://www.taxjustice.net/about/who-we-are/goals/, accessed November 2017.

Tax Justice Network and PWYP (2015). Submission on the Tax Laws Amendment (Tax Integrity Multinational Anti-avoidance Law) Bill 2015: Country by country reporting and Tax and Superannuation Laws Amendment (2015 Measures No. 4) Bill 2015: Scheme penalties for large companies 2 September 2015.

Thornton, P. and Ocasio, W. (2008). Institutional Logics. In R Greenwood, C.Oliver, K Sahlin and R. Suddaby (Eds), The Sage handbook of organisational institutionalism. London: Sage.

Transparency International (2011). The 2011 corruption perceptions index measures the perceived levels of public sector corruption in 183 countries and territories around the world. https://www.transparency.org/cpi2011, accessed November 2017

Transparency International (2017). What is Transparency International? Available at: https://www.transparency.org/about/, accessed June 2017.

Transparency International (2015). Comment letter in response to the BIS consultation transposition of the Accounting Directive. Available at: https://www.gov.uk/government/consultations/eu-accounting-directive-smaller-companiesreporting, accessed June 2016. 
US Treasury (2009). Financial Regulatory Reform - A New Foundation: Rebuilding Financial Supervision and Regulation. The Department of the Treasury: USA. Available at: https://www.iasplus.com/en/news/2009/June/news5025, accessed June 2017.

Veron, N. (2007). EU Adoption of the IFRS 8 Standard on Operating Segments: Presentation to the Economic and Monetary Affairs Committee of the European Parliament. Available at: http://veron.typepad.com/main/files/EuroParl_IFRS8_Sep07.pdf, re-accessed March 2012.

Whittington, G. (2005). The adoption of international accounting standards in the European Union. European Accounting Review, 14 (1), 127-153.

Williams, P. (2013). Happy. In P. Williams, Girl. New York: Columbia Records.

Williams, J. (2015). Five years and counting: the SEC must step up and make natural resource payment disclosure rule. Available at: http://www.resourcegovernance.org/news/blog/five-yearsand-counting-sec-must-step-and-make-natural-resource-payment-disclosure-rule, accessed August 2015.

Young, J.J. (2003). Constructing, persuading and silencing: the rhetoric of accounting standardsetting. Accounting Organizations and Society, 28 (6), 621-638. 